\title{
Hepatitis C virus core protein targets 4E-BP1 expression and phosphorylation and potentiates Myc-induced liver carcinogenesis in transgenic mice
}

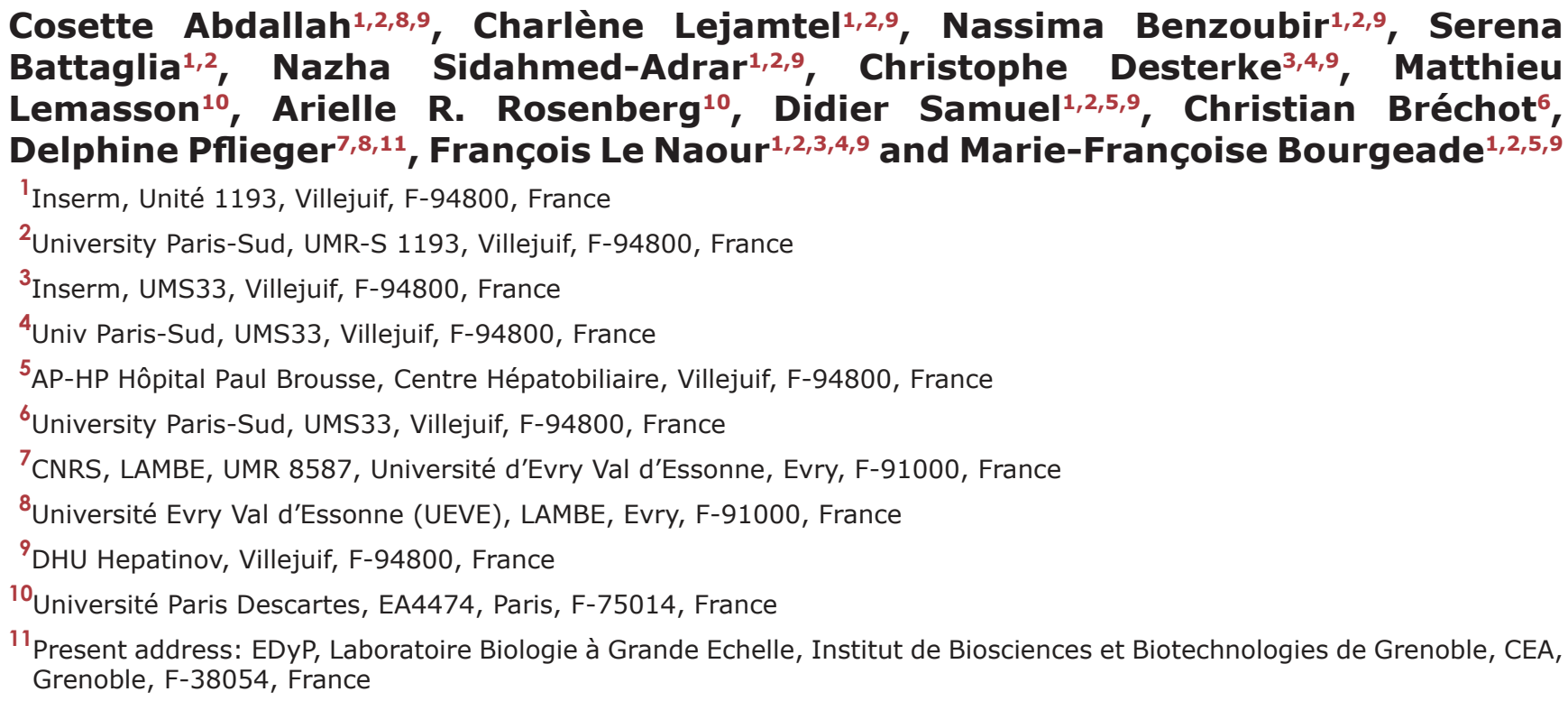

Correspondence to: François Le Naour, email: francois.le-naour@inserm.fr

Keywords: HCV core, 4E-BP1 phosphorylation, hepatocellular carcinoma, phosphoproteomics, SILAC

Received: December 07, $2015 \quad$ Accepted: March 27, $2017 \quad$ Published: April 20, 2017

Copyright: Abdallah et al. This is an open-access article distributed under the terms of the Creative Commons Attribution License 3.0 (CC BY 3.0), which permits unrestricted use, distribution, and reproduction in any medium, provided the original author and source are credited.

\section{ABSTRACT}

Hepatitis C virus (HCV) is a leading cause of liver diseases including the development of hepatocellular carcinoma (HCC). Particularly, core protein has been involved in HCV-related liver pathologies. However, the impact of HCV core on signaling pathways supporting the genesis of HCC remains largely elusive. To decipher the host cell signaling pathways involved in the oncogenic potential of HCV core, a global quantitative phosphoproteomic approach was carried out. This study shed light on novel differentially phosphorylated proteins, in particular several components involved in translation. Among the eukaryotic initiation factors that govern the translational machinery, 4E-BP1 represents a master regulator of protein synthesis that is associated with the development and progression of cancers due to its ability to increase protein expression of oncogenic pathways. Enhanced levels of 4E-BP1 in non-modified and phosphorylated forms were validated in human hepatoma cells and in mouse primary hepatocytes expressing HCV core, in the livers of HCV core transgenic mice as well as in HCV-infected human primary hepatocytes. The contribution of HCV core in carcinogenesis and the status of 4E-BP1 expression and phosphorylation were studied in HCV core/ Myc double transgenic mice. HCV core increased the levels of 4E-BP1 expression and phosphorylation and significantly accelerated the onset of Myc-induced tumorigenesis in these double transgenic mice. These results reveal a novel function of HCV core in liver carcinogenesis potentiation. They position 4E-BP1 as a tumor-specific target of HCV core and support the involvement of the 4E-BP1/eIF4E axis in hepatocarcinogenesis. 


\section{INTRODUCTION}

Hepatocellular carcinoma (HCC) is the sixth most prevalent cancer and the second most common cause of cancer-related deaths worldwide. Its incidence is still increasing [1]. Hepatitis C Virus (HCV) infection is one of the major etiologies of HCC. Major progress in HCV therapy now leads to envisage the eradication of $\mathrm{HCV}$ infection in a near future. However, these new treatments do not directly interfere with liver carcinogenesis and therefore many patients already at the stage of HCV-induced cirrhosis will still develop HCC. Furthermore, there is accumulating evidence that there are common pathways and related mechanisms that likely account for viral and non-viral pathogenesis of cancers [2]. Thus, elucidating the pathways implicated in the progression of $\mathrm{HCV}$-induced liver disease and $\mathrm{HCC}$ is still an unmet need for developing novel therapeutic approaches.

The involvement of viral and host factors in the progression of $\mathrm{HCV}$-induced liver disease is intricate. It has been suggested that $\mathrm{HCV}$-encoded proteins are directly involved in the tumorigenic process through interaction with a number of host factors and signaling pathways. Extensive studies have suggested that HCV core protein binds several cellular proteins and plays a major role in $\mathrm{HCV}$-induced liver pathologies by modulating multiple cellular processes. Among them, we have reported that $\mathrm{HCV}$ core protein inhibits the canonic TGF- $\beta$ signaling pathway [3] and shifts its biological responses from tumor suppression to tumor progression by decreasing hepatocyte apoptosis and increasing epithelial mesenchymal transition (EMT) [4]. Strikingly, an HCV core sequence isolated from an HCC nodule was more potent to inhibit TGF- $\beta$ signaling than a core sequence isolated from the adjacent non-tumor tissue, highlighting the ability of $\mathrm{HCV}$ core variants to display different biological host responses [4].

Several studies conducted on transgenic animal models have reported that $\mathrm{HCV}$ core expression led to either no particular phenotype [5], steatosis [6,7], insulin resistance $[8,9]$, modulation of apoptosis $[10,11]$ or even HCC development [12]. This is consistent with the notion that these various observations might be correlated with HCV genotype, mouse genetic background [13], or $\mathrm{HCV}$ core levels related to the chosen promoter as well as with core sequences used in the different studies. The establishment of transgenic mouse models expressing core sequences isolated from tumor or non-tumor nodules of the same patient would be an invaluable tool to investigate the pathological potential of these $\mathrm{HCV}$ core variants and the molecular basis downstream.

To decipher the molecular events involved in the oncogenic potential of $\mathrm{HCV}$ core, a global quantitative phosphoproteomic approach of HCV core expressing cells represents a highly valuable tool to investigate the activation or repression of host cell signaling transduction pathways. Indeed, no data are available on the global profile of the HCV core regulated phosphoproteome. We here report the identification of a panel of proteins phosphorylated in $\mathrm{HCV}$ core expressing cells involved in metabolism, cell death, protein transport and cellular component organization as well as in the regulation of translation. In particular, we demonstrated that $\mathrm{HCV}$ core activates a pathway increasing the phosphorylated level of the key translation factor eukaryotic translation initiation factor 4E-binding protein 1 (4E-BP1) in primary human and mouse hepatocytes as well as in HCV core transgenic mouse livers. We also report that $\mathrm{HCV}$ core is able to potentiate Myc-induced tumor development in double transgenic mice and 4E-BP1 might be responsible for this acceleration of tumor progression.

\section{RESULTS}

\section{Quantitative phosphoproteomic analysis of hepatoma cell line expressing HCV core protein}

A SILAC-based phosphoproteomic approach was applied to unveil the signal transduction pathways modulated by $\mathrm{HCV}$ core protein. Hence, $\mathrm{HuH} 7$ and $\mathrm{HuH} 7$ expressing $\mathrm{HCV}$ core protein were cultured in SILAC media for metabolic labeling. Cells were lysed and the protein lysates were pooled in equimolar ratio prior to in-solution trypsin digestion. Phosphopeptides were further selectively enriched using an immobilized metal affinity chromatography (IMAC) resin and then analyzed by liquid chromatography coupled to tandem mass spectrometry (LC-MS/MS). The strategy exhibited the major advantage to allow simultaneously identification and accurate quantification of phosphorylated proteins under the different conditions. This state-of-the-art proteomic approach was applied to the cellular models in three independent SILAC experiments and led to the identification of 7 proteins down-phosphorylated and 24 proteins hyper-phosphorylated in HCV core expressing cells (Table 1). In addition, 16 out of the 35 differentially phosphorylated peptides exhibited a modulation of phosphorylation within the (Ser/Thr)-Pro motif, broadly recognized as potential MAP kinase and mTORC1 target sites [14], indicating that the (Ser/Thr)-Pro motif is essential for dynamic signaling transduction in HCVcore-expressing cells [15]. A functional network was built by investigating the functions of the identified proteins into Go Elite database and visualized in Cytoscape program. This approach revealed that the phosphoproteins modulated by $\mathrm{HCV}$ core were prominently involved in metabolism (carbohydrate and lipid biosynthetic processes), insulin receptor signaling, protein transport, cell death, cellular component organization and translation (Figure 1). 
Table 1: Proteins and peptides with modulated phosphorylation in HuH7 cells expressing $\mathrm{HCV}$ core protein

\begin{tabular}{|c|c|c|c|c|c|c|c|c|}
\hline \multicolumn{9}{|c|}{ Ratio cT/WT } \\
\hline $\begin{array}{c}\text { Gene } \\
\text { Names }\end{array}$ & $\begin{array}{c}\text { Accession } \\
\text { number }\end{array}$ & Protein Names & Modified sequence & $\begin{array}{c}\text { Probabilities of } \\
\text { phosphorylation } \\
\text { on STY }\end{array}$ & $\begin{array}{l}\text { Phosphorylated } \\
\text { position }\end{array}$ & $\mathrm{S}_{1}$ & $\mathrm{~S}_{2}$ & $\mathrm{~S}_{3}$ \\
\hline \multirow{2}{*}{ BCKDHA } & \multirow{2}{*}{ F5H5P2 } & \multirow{2}{*}{$\begin{array}{l}\text { 2-oxoisovalerate dehydrogenase } \\
\text { subunit alpha, mitochondrial }\end{array}$} & $\begin{array}{l}\text { IGHHS(ph)T(ph) } \\
\text { SDDSSAYRSVDEVNYWDKQDHPISR }\end{array}$ & $\mathrm{S}(0.424) \mathrm{T}(0.424)$ & S371/T372 & 2.58 & - & - \\
\hline & & & $\begin{array}{l}\text { IGHHS(ph)TSDDSSAY(ph) } \\
\text { RSVDEVNYWDK }\end{array}$ & $\begin{array}{l}\mathrm{S}(0.748) \\
\mathrm{Y}(0.283)\end{array}$ & S371/Y379 & - & 2.36 & 1.54 \\
\hline SNTB1 & Q13884 & Beta-1-syntrophin & LVHSGPGKGS(ph)PQAGVDLSFATR & $\mathrm{S}(1)$ & S389 & 3.8 & 1.67 & 1.83 \\
\hline SH3KBP1 & Q96B97 & $\begin{array}{l}\text { SH3 domain-containing kinase- } \\
\text { binding protein } 1\end{array}$ & S(ph)IEVENDFLPVEK & $\mathrm{S}(1)$ & S230 & 2.05 & - & 2.08 \\
\hline \multirow{2}{*}{$\begin{array}{l}\text { RPS6KA3; } \\
\text { RPS6KA6 }\end{array}$} & \multirow{2}{*}{ P51812 } & \multirow{2}{*}{$\begin{array}{l}\text { Ribosomal protein S6 kinase } \\
\text { alpha-3 }\end{array}$} & KAYS(ph)FCGTVEYMAPEVVNRR & $\mathrm{S}(0.987)$ & S227 & & 2.57 & \\
\hline & & & TPKDS(ph)PGIPPSANAHQLFR & $\mathrm{S}(0.998)$ & S369 & 1.5 & 3.98 & 1.77 \\
\hline SDAD1 & Q9NVU7 & Protein SDA1 homolog & YIEIDS(ph)DEEPRGELLSLR & $\mathrm{S}(1)$ & S585 & 2.11 & 1.7 & 1.5 \\
\hline FAM122A & Q96E09 & Protein FAM122A & RIDFIPVS(ph)PAPS(ph)PTR & $\mathrm{S}(1) \mathrm{S}(0.99)$ & S143/S147 & & 2.03 & 1.59 \\
\hline EIF4EBP1 & Q13541 & $\begin{array}{l}\text { Eukaryotic translation initiation } \\
\text { factor } 4 \mathrm{E}-\text { binding protein } 1\end{array}$ & $\begin{array}{l}\text { RVVLGDGVQLPPGDYSTT(ph) } \\
\text { PGGTLFSTT(ph)PGGTR }\end{array}$ & $\begin{array}{l}\mathrm{T}(0.968) \\
\mathrm{T}(0.493)\end{array}$ & T37/T46 & 1.15 & 2.95 & 2.23 \\
\hline EIF4EBP2 & Q13542 & $\begin{array}{l}\text { Eukaryotic translation initiation } \\
\text { factor 4E-binding protein } 2\end{array}$ & $\begin{array}{l}\text { TVAISDAAQLPHDYCTT(ph) } \\
\text { PGGTLFSTT(ph)PGGTR } \\
\end{array}$ & $\mathrm{T}(0.5) \mathrm{T}(0.469)$ & $\mathrm{T} 37 / \mathrm{T} 46$ & - & 1.96 & 1.81 \\
\hline SRP72 & O76094 & $\begin{array}{c}\text { Signal recognition particle } 72 \mathrm{kDa} \\
\text { protein }\end{array}$ & $\begin{array}{l}\text { TVSSPPTS(ph)PRPGS(ph) } \\
\text { AATVSASTSNIIPPR }\end{array}$ & $\mathrm{S}(0.31) \mathrm{S}(0.354)$ & $\mathrm{S} 625 / \mathrm{S} 630$ & - & 2.03 & 1.81 \\
\hline \multirow{2}{*}{ EHBP1 } & \multirow{2}{*}{ Q8NDI1 } & \multirow{2}{*}{ EH domain-binding protein 1} & DLSTS(ph)PKPSPIPS(ph)PVLGR & $\mathrm{S}(0.739) \mathrm{S}(0.998)$ & S428/S436 & 1.67 & & 2 \\
\hline & & & \begin{tabular}{|l|l|} 
DLSTS(ph)PKPS(ph)PIPS(ph)PVLGR \\
\end{tabular} & $\mathrm{S}(0.401) \mathrm{S}(1) \mathrm{S}(1)$ & S428/S432/S436 & 1.52 & 2.29 & 2 \\
\hline TMPO & P42167 & $\begin{array}{c}\text { Lamina-associated polypeptide } 2, \\
\text { isoforms beta/gamma }\end{array}$ & $\begin{array}{l}\text { GPPDFS(ph)S(ph)DEEREPT(ph) } \\
\text { PVLGSGAAAAGR }\end{array}$ & $\mathrm{S}(1) \mathrm{S}(1) \mathrm{T}(0.987)$ & S66/S67/T74 & - & 2.08 & 1.52 \\
\hline SEC16A & J3KNL6 & Protein transport protein Sec16A & $\begin{array}{l}\text { GSVSQPS(ph)T(ph)PS(ph) } \\
\text { PPKPTGIFQTSANSSFEPVK }\end{array}$ & $\begin{array}{c}\mathrm{S}(0.715) \mathrm{T}(0.715) \\
\mathrm{S}(0.81)\end{array}$ & S592/T593/S595 & - & 2.97 & 1.88 \\
\hline TPI1 & 60174 & Triosephosphate isomerase & KQS(ph)LGELIGTLNAAK & $\mathrm{S}(1)$ & S58 & 1.63 & 2.41 & 2.79 \\
\hline \multirow{2}{*}{ NUCKS1 } & \multirow{2}{*}{ Q9H1E3 } & \multirow{2}{*}{$\begin{array}{c}\text { Nuclear ubiquitous casein and } \\
\text { cyclin-dependent kinase substrate } \\
1\end{array}$} & $\begin{array}{l}\text { KVVDYS(ph) } \\
\text { QFQESDDADEDYGRDSGPPTK }\end{array}$ & $\mathrm{S}(0.526)$ & S14 & - & 2.2 & 1.79 \\
\hline & & & $\begin{array}{l}\text { VVDYSQFQES(ph) } \\
\text { DDADEDYGRDSGPPTK }\end{array}$ & $\mathrm{S}(0.992)$ & S19 & - & 2.07 & 1.82 \\
\hline $\begin{array}{l}\text { FAM21A; } \\
\text { FAM21B }\end{array}$ & Q641Q2 & $\begin{array}{c}\text { WASH complex subunit } \\
\text { FAM21A;WASH complex subunit } \\
\text { FAM21B } \\
\end{array}$ & $\begin{array}{l}\text { ASALLFS(ph)S(ph) } \\
\text { DEEDQWNIPASQTHLASDSR }\end{array}$ & $\mathrm{S}(0.999) \mathrm{S}(1)$ & S619/S620 & - & 1.51 & 2.69 \\
\hline CDS2 & O95674 & \begin{tabular}{|c|} 
Phosphatidate cytidylyltransferase \\
2
\end{tabular} & $\begin{array}{l}\text { VAHEPVAPPEDKES(ph) } \\
\text { ESEAKVDGET(ph)ASDSESR }\end{array}$ & $\mathrm{S}(0.714) \mathrm{T}(0.537)$ & $\mathrm{S} 21 / \mathrm{T} 31$ & - & 1.59 & 2.39 \\
\hline MAP4 & E7EVA0 & Microtubule-associated protein 4 & DMES(ph)PTKLDVTLAK & $\mathrm{S}(0.995)$ & S297 & & 2.27 & 2.2 \\
\hline EIF4B & E7EX17 & $\begin{array}{l}\text { Eukaryotic translation initiation } \\
\text { factor } 4 \mathrm{~B}\end{array}$ & $\begin{array}{l}\text { SLENETLNKEEDCHSPT(ph) } \\
\text { SKPPKPDQPLK }\end{array}$ & $\mathrm{T}(0.917)$ & T466 & - & 1.63 & 3.39 \\
\hline SYAP1 & Q96A49 & Synapse-associated protein 1 & EQDLPLAEAVRPKT(ph)PPVVIK & $\mathrm{T}(1)$ & T248 & 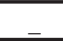 & 2.37 & 1.52 \\
\hline HMGCS1 & Q01581 & $\begin{array}{l}\text { Hydroxymethylglutaryl-CoA } \\
\text { synthase, cytoplasmic }\end{array}$ & $\begin{array}{l}\text { RPTPNDDTLDEGVGLVHSNIATEHIPS(ph) } \\
\text { PAK }\end{array}$ & $\mathrm{S}(0.999)$ & S495 & 1.52 & - & 3.82 \\
\hline EPB41L2 & O43491 & Band 4.1-like protein 2 & EVRS(ph)PTKAPHLQLIEGK & $\mathrm{S}(1)$ & S598 & & 1.77 & 2.16 \\
\hline EPPK1 & P58107 & Epiplakin & RQVS(ph)ASELHTSGILGPETLR & $\mathrm{S}(0.918)$ & S2716 & 1.71 & 2 & \\
\hline $\mathrm{ABCF} 1$ & Q8NE71 & $\begin{array}{c}\text { ATP-binding cassette sub-family F } \\
\text { member } 1\end{array}$ & KLS(ph)VPT(ph)S(ph)DEEDEVPAPKPR & $\mathrm{S}(1) \mathrm{T}(1) \mathrm{S}(1)$ & S105/T108/S109 & 2.69 & 2.12 & - \\
\hline HSPB1 & P04792 & Heat shock protein beta-1 & GPS(ph)WDPFRDWYPHSR & $\mathrm{S}(1)$ & $\mathrm{S} 15$ & 4.21 & 3.02 & 2.99 \\
\hline TJP1 & G3V1L9 & Tight junction protein $\mathrm{ZO}-1$ & $\begin{array}{l}\text { VQIPVSRPDPEPVS(ph)DNEEDSY(ph) } \\
\text { DEEIHDPR }\end{array}$ & $\begin{array}{l}\mathrm{S}(0.963) \\
\mathrm{Y}(0.783)\end{array}$ & $\mathrm{S} 125 / \mathrm{Y} 132$ & 0.54 & 0.55 & - \\
\hline HNF1B & P35680 & Hepatocyte nuclear factor 1-beta & GRLS(ph)GDEGS(ph)EDGDDYDTPPILK & $\mathrm{S}(1) \mathrm{S}(1)$ & $\mathrm{S} 75 / \mathrm{S} 80$ & 0.39 & 0.38 & - \\
\hline EPS8L3 & \begin{tabular}{|c|} 
Q8TE67- \\
3
\end{tabular} & $\begin{array}{l}\text { Epidermal growth factor receptor } \\
\text { kinase substrate 8-like protein } 3\end{array}$ & RS(ph)SS(ph)PEDPERDEEVLNHVLR & $\mathrm{S}(0.667) \mathrm{S}(0.667)$ & S229/S231 & 0.46 & 0.4 & - \\
\hline LRP2 & P98164 & $\begin{array}{c}\begin{array}{c}\text { Low-density lipoprotein receptor- } \\
\text { related protein } 2\end{array} \\
\end{array}$ & ES(ph)VAATPPPS(ph)PSLPAKPKPPSR & $\mathrm{S}(0.942) \mathrm{S}(0.958)$ & S4608/S4616 & 0.2 & 0.26 & - \\
\hline RAB11FIP1 & Q6WKZ4 & Rab11 family-interacting protein 1 & $\begin{array}{l}\text { HLFSS(ph) } \\
\text { TENLAAGSWKEPAEGGGLSSDR }\end{array}$ & $\mathrm{S}(0.805)$ & S357 & 0.31 & 0.46 & - \\
\hline KRT18 & P05783 & Keratin, type I cytoskeletal 18 & $\begin{array}{l}\text { STSFRGGMGS(ph) } \\
\text { GGLATGIAGGLAGMGGIQNEK }\end{array}$ & $S(0.776)$ & S60 & - & 0.32 & 0.55 \\
\hline SQSTM1 & Q13501 & Sequestosome-1 & $\begin{array}{l}\text { KIALESEGRPEEQMES(ph)DNCS(ph) } \\
\text { GGDDDWTHLSSK }\end{array}$ & $\mathrm{S}(0.997) \mathrm{S}(0.998)$ & S328/S332 & - & 0.54 & 0.41 \\
\hline
\end{tabular}

The table encompasses the genes, protein names and their accession numbers according to the UniProt-SwissProt database. In the peptide sequences, (ph) after S/T/Y residue indicates the phosphorylated status. The probability for the site of phosphorylation was calculated by MaxQuant. The study was performed in biological triplicate $\left(\mathrm{S}_{1} / \mathrm{S}_{2} / \mathrm{S}_{3}\right)$ and Phosphorylated peptides were considered to be significantly regulated when exhibiting an abundance ratio core/WT exceeding mean +1.96 standard deviation in at least two replicates. 
HCV core protein enhances the level of phosphorylated 4E-BP1 in human hepatoma cells and primary hepatocytes

Among the proteins appearing substantially hyperphosphorylated in HCV core protein expressing cells compared to the control, several components involved in translation were identified such as the eukaryotic translation initiation factor 4B (EIF4B) and the eukaryotic translation initiation factors 4E-binding protein 1 (4E-BP1) and 2 (4E-BP2). These proteins play a critical role in protein synthesis control [16] and their deregulation is associated with the development and progression of cancers because components of the translational machinery function at the point of convergence of deregulated cell signaling pathways.

We further focused on 4E-BP1 phosphorylation because this event is critical in causing 4E-BP1 dissociation from eIF4E, which leaves $4 \mathrm{E}$ available to form the translationally active eIF4F complex and then results in switching on mRNA translation, which may contribute to changes in gene expression associated with malignant transformation [17]. To validate the phosphoproteomic findings and evaluate the state of 4E-BP1 phosphorylation on Thr 37/46, lysates prepared from HuH7 WT cells and $\mathrm{HuH7}$ cells stably expressing core protein variants either isolated from tumor cT or non-tumor cirrhotic $(\mathrm{cNT})$ areas, were analyzed by immunoblotting using an antibody that recognizes exclusively the dual phosphorylation on the residues Thr37/46. The amount of 4E-BP1 phosphorylated on $\mathrm{Thr} 37$ and Thr46 was significantly higher in $\mathrm{HuH} 7 \mathrm{cT}$ and cNT cells compared to $\mathrm{HuH} 7 \mathrm{WT}$ cells (Figure 2A and 2B), which matched and validated the aforementioned SILAC-based phosphoproteomics findings. The same increase in phosphorylated 4E-BP1 was observed with both core variants although the cNT was much more expressed than the $\mathrm{cT}$ (Figure 2B). In accordance with numerous previous studies, 4E-BP1 and its phosphorylated form are detected as multiple bands on gels in the vicinity of $20 \mathrm{kDa}$ [18]. Moreover, an increased amount of phosphorylated 4E-BP1 was associated with an enhancement of 4E-BP1 expression in agreement with previously reported studies [19]. 4E-BP1 phosphorylation on Thr37/46 primes its subsequent phosphorylation on Ser65 and Thr70, decreasing its affinity for eIF4E, which allows eIF4G and associated factors to bind to eIF4E [17]. Therefore, these potential 4E-BP1 phosphorylation sites were investigated by immunoblotting using specific antibodies. As shown in Figure 2C and 2D, an increase of phosphorylated 4E-BP1 at Ser65 and Thr70 was observed in $\mathrm{HuH} 7$ cells expressing both $\mathrm{HCV}$ core cT and cNT compared to $\mathrm{HuH7}$ WT.

To further substantiate the assumption of the HCV core protein-driven increase of phosphorylated 4E-BP1,

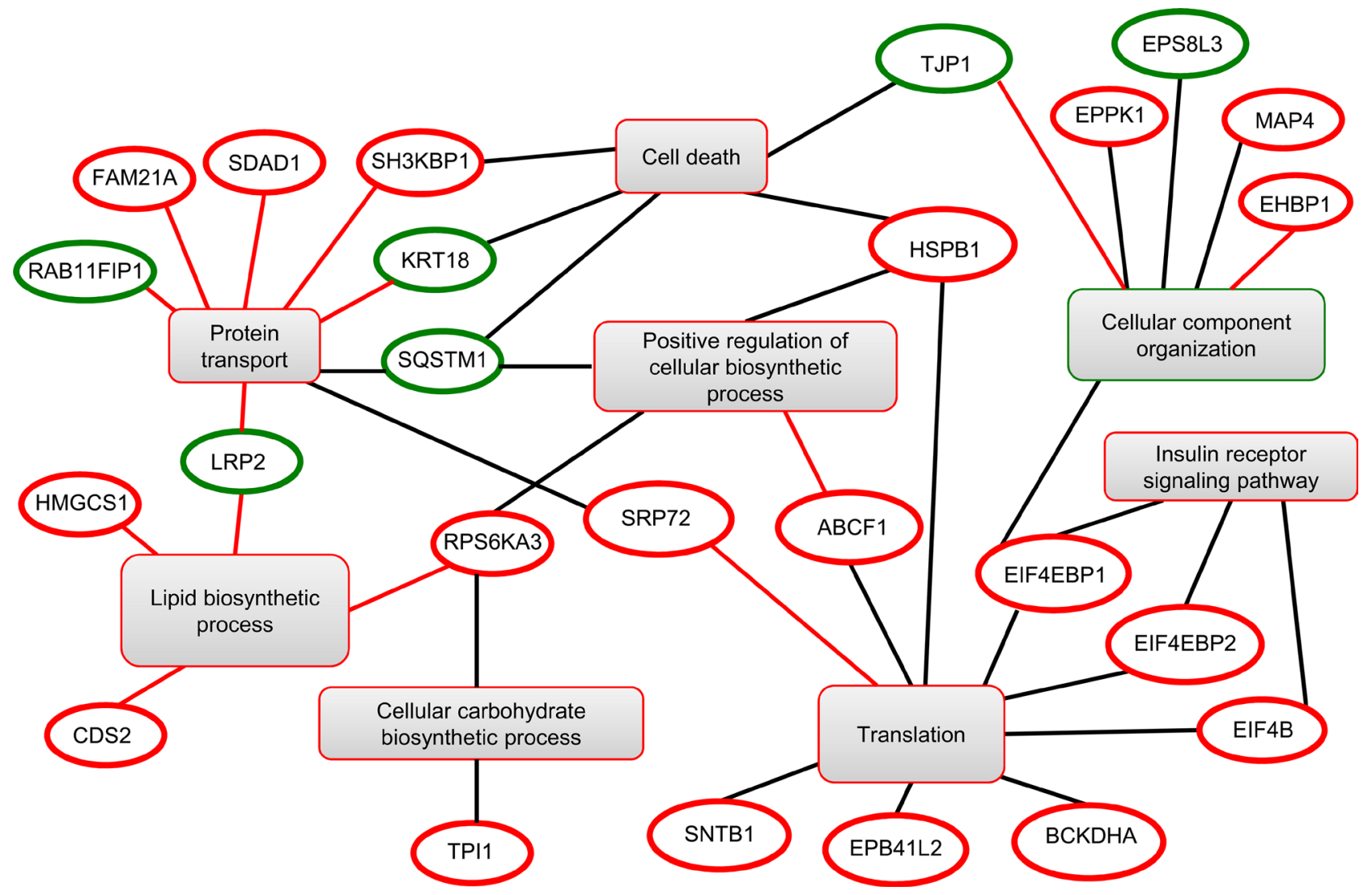

Figure 1: Functional clustering of the differentially modulated phosphoproteins identified by phosphoproteomics. Red and green circles correspond to up- and down-phosphorylated proteins, respectively. 
human HuH9.13 cell line, harboring HCV NS3-NS5B subgenomic replicon, was herein used together with controls cured from the replicon. Interestingly but unexpectedly, HuH9.13 exhibited a drastically lower level of phospho4E-BP1 on Thr37/46, Ser65 and Thr70 compared to HuH7 $\mathrm{cT} / \mathrm{cNT}$ in immunoblot analysis (Figure $2 \mathrm{~A}-2 \mathrm{D}$ ). Whereas previous studies have shown that NS5A expressing cells (NS5A-HuH7.5) induce 4E-BP1 hyper-phosphorylation [20], a very weak signal was detected with the HuH9.13 used in this study, despite NS5A expression (Figure 2A-2D). Moreover, the increase in 4E-BP1 phosphorylation was also observed in HuH7.5 cells expressing the entire replicon (Figure 2E), confirming the efficacy of $\mathrm{HCV}$ core to promote 4E-BP1 phosphorylation in presence of all $\mathrm{HCV}$ proteins. Similarly, phospho-4E-BP1 levels were enhanced in JFH1-infected HuH7.5.1 in comparison with mock cells (Figure 2F). Notably, the enhancement in 4E-BP1 phosphorylation was likewise retrieved in primary human hepatocytes infected with JFH1 (Figure 2G). Strikingly fold changes of phospho-4EBP1 normalized to 4E-BP1 expression were not significantly different in hepatoma cell lines, however it turned significant in primary human hepatocytes (Figure 2B, 2G). This observation could be linked to the derivation of the $\mathrm{HuH} 7$ cell line from an $\mathrm{HCC}$ since it has been reported that 4E-BP1 phosphorylation was already increased in HCC tissues [19].

Taken together, these data experimentally confirmed the quantitative phosphoproteomic findings and strongly support the hypothesis that both HCV core variants $\mathrm{cT}$ and cNT induce 4E-BP1 dual phosphorylation in a hepatoma cell line. Importantly this effect was also observed in $\mathrm{HCV}$-infected primary human hepatocytes.

\section{HCV core promotes $4 \mathrm{E}-\mathrm{BP} 1$ phosphorylation in vivo}

The above-mentioned in vitro observations raised the question of whether HCV core protein could drive an increase in the level of phosphorylated 4E-BP1 in vivo. Therefore, we used transgenic mice harboring two core variant sequences cT and $\mathrm{cNT}$ [4]. These mice did not exhibit demonstrable deficits in growth or development and no cellular inflammatory infiltrate was evident in their livers. Interestingly, when liver proteins extracted from these transgenic mice were analyzed for core by Western blot, a strong signal was detected at the expected $20 \mathrm{kDa}$ in $\mathrm{cNT}$, whereas a faint signal was visible in cT. To check the transcription level of HCV core, RNA was isolated from 3 different WT, cT and cNT transgenic mouse livers, reverse transcribed into cDNA, amplified and quantified by qPCR for HCV core gene. The same transcription level of HCV core messenger in cT and cNT mouse livers was detected (Supplementary Figure 1). Thus, the low protein level of HCV core cT could be related to its instability and its further degradation. This hypothesis was confirmed by a significant increase of $\mathrm{cT}$ protein expression in cells treated with MG132, a proteasome inhibitor, which effectively blocks the proteolytic activity of the $26 \mathrm{~S}$ proteasome complex (Supplementary Figure 1).

To study the 4E-BP1 phosphorylation status in the liver of these transgenic animals, Western blot assays were performed on different 9-month-old mouse liver protein lysates and a representative example of protein extracts from four mice per group is shown in Figure 3. In agreement with in vitro data, immunoblotting of lysates from cT and cNT mouse liver showed a significant $\mathrm{HCV}$ core protein dependent increase of 4E-BP1 phosphorylation on Thr37/46 in comparison with the WT (Figure 3A and 3B). Of note, the observations made in vivo not only indicated an increased amount of phosphorylated 4E-BP1 at constant phosphorylation stoichiometry as it was the case in vitro; this time cT and cNT also enhanced the phosphorylation level of the protein 4E-BP1. Furthermore, immunohistochemical staining of p4E-BP1 was performed on transgenic mouse livers. Figure $3 \mathrm{C}$ shows the increase in $\mathrm{p} 4 \mathrm{E}-\mathrm{BP} 1$ in $\mathrm{cT}$ and cNT mouse livers compared to the WT. Next, it was relevant to explore the phosphorylation state of 4E-BP1 in primary cultured mouse hepatocytes isolated from WT and transgenic mouse livers expressing either HCV core protein variant $\mathrm{cT}$ or $\mathrm{cNT}$. To this end, we compared the phosphorylation changes of 4E-BP1 by Western blot assays. Although the total 4E-BP1 expression was found to be enhanced in transgenic mouse livers a significant phosphorylation increase of 4E-BP1 in cT and cNT mouse hepatocytes was observed (Figure 3D and 3E). Shutdown of 4E-BP1 phosphorylation was observed in core primary mouse hepatocytes upon treatment with MEK/ERK and mTORC1 inhibitors, suggesting that these signaling pathways could be involved in the increase of 4E-BP1 phosphorylation by HCV core protein (Supplementary Figure 2).

Altogether these results corroborate the assumption that $\mathrm{HCV}$, through core protein, enhances both total protein level and phosphorylation stoichiometry of 4E-BP1 in hepatocytes of transgenic mouse livers.

\section{HCV core induces the expression of MTA1, a 4E-BP1 downstream target}

It has been reported that expression of a non phosphorylable 4E-BP1 mutant decreases YB1, vimentin, CD44 and MTA1 expressions at the protein but not mRNA level and thus could represent downstream targets of 4E-BP1 [21]. Among them, we chose to study MTA1 expression because this protein was reported to be highly expressed in HCC and served as an indicator of poor prognosis in HCC patients [22]. Our results show that increased expression of the phosphorylated forms of 4E-BPlinduced by HCV core in HuH7 (Figure 4A) as well as in mouse livers was associated with a marked increase in MTA1 expression (Figure 4B). Consistent with 
A

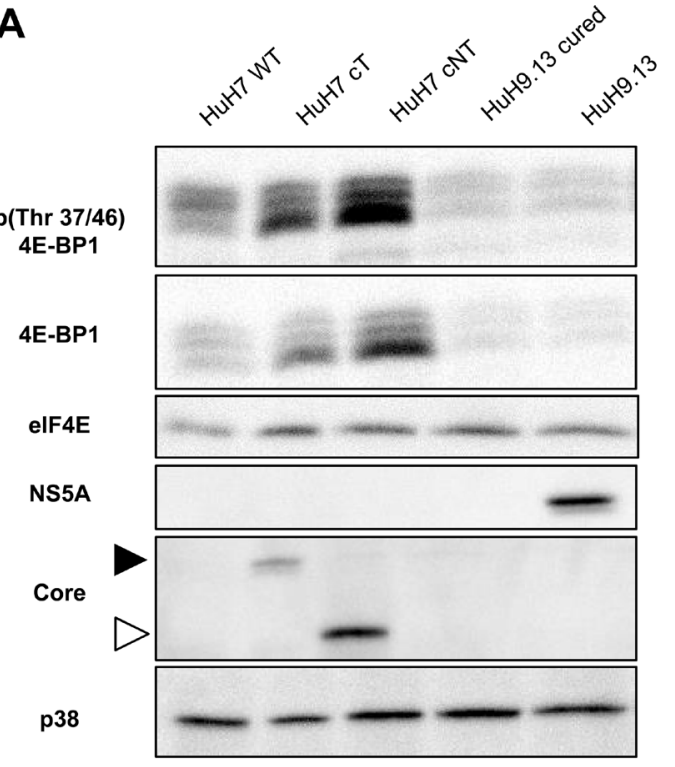

C

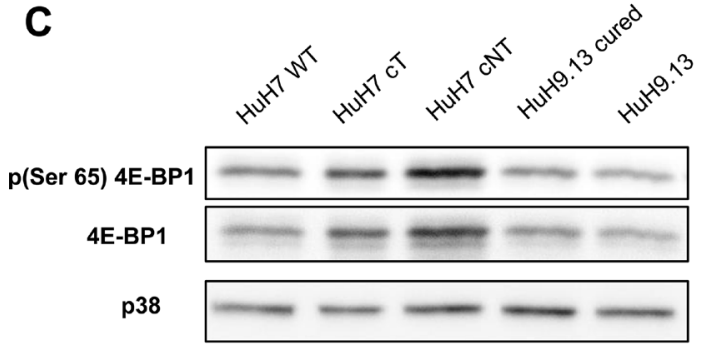

B

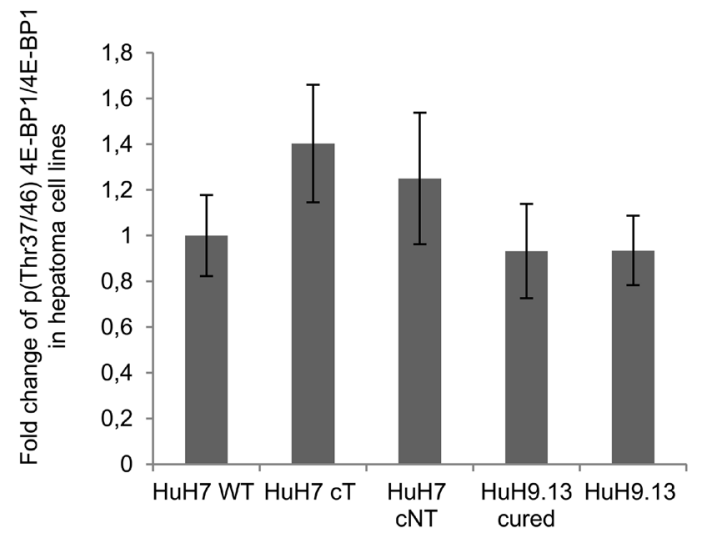

D

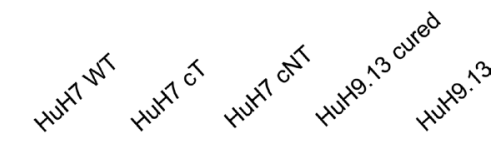

p(Thr 70) 4E-BP1

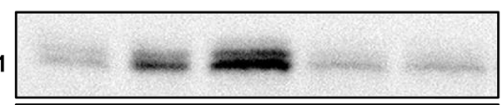

4E-BP1

p38

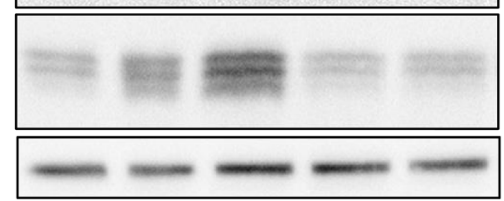

Primary human

hepatocytes

$\mathbf{E}$
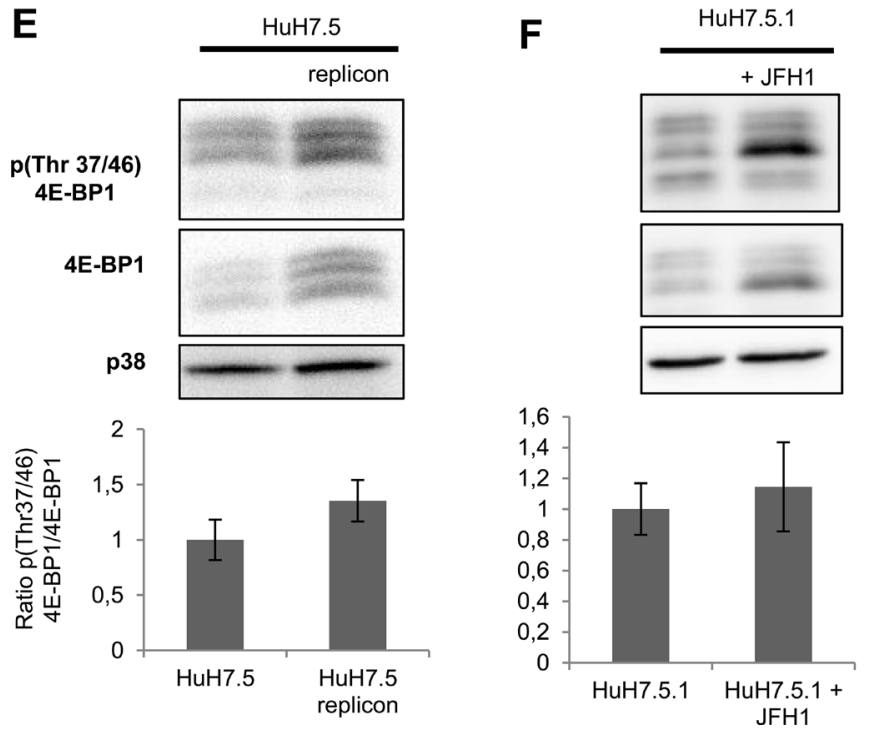

G
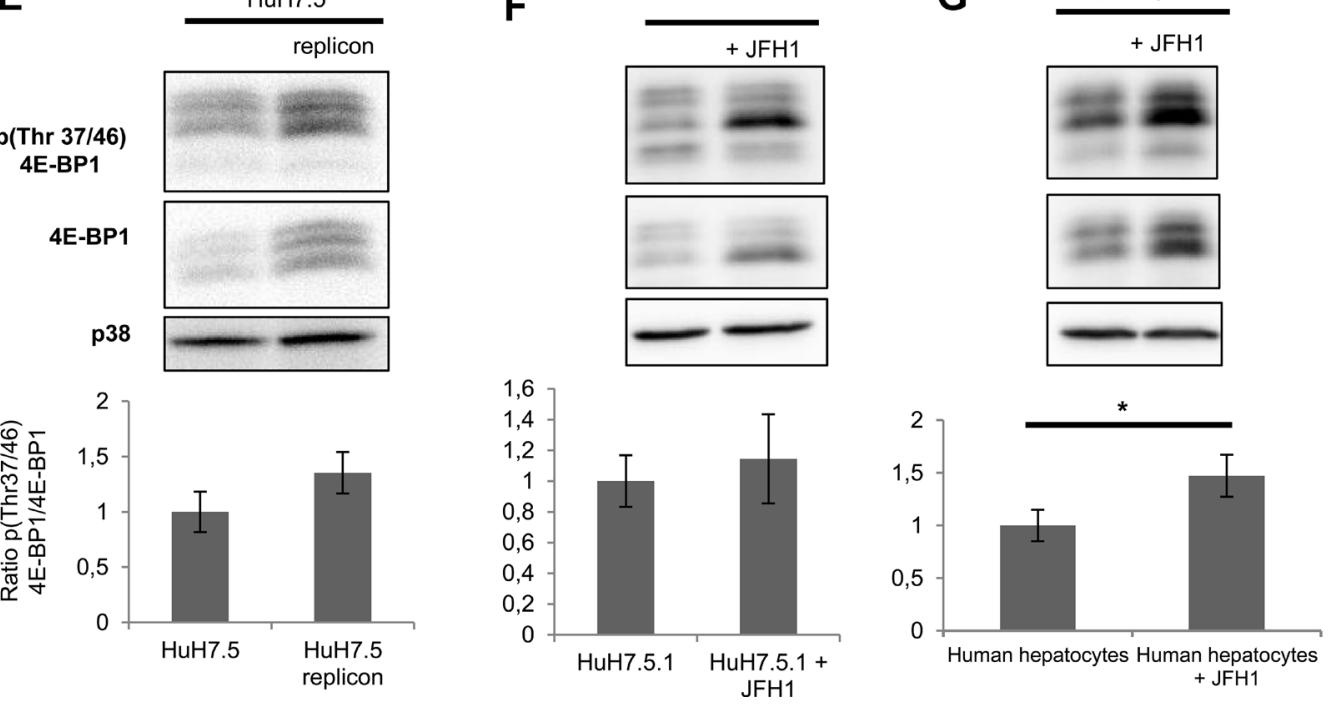

Figure 2: HCV core protein increases the level of phosphorylated 4E-BP1. (A) Immunoblotting analysis of 4E-BP1 phosphorylation on $\mathrm{Thr} 37 / 46$ in lysates of $\mathrm{HuH7}$ controls (WT), HuH7 stably expressing core protein variants either isolated from tumor or non-tumor cirrhotic (cT or $\mathrm{cNT}$ ) areas and HuH9.13 harboring the HCV NS3-NS5B subgenomic replicon and its related control (HuH9.13 cured). HCV NS5A and core expressions are shown. When the membrane was probed with an antibody directed against core antibody, an expected signal at $20 \mathrm{kDa}$ was obtained in $\mathrm{HuH} 7 \mathrm{cNT}$ (white arrow), however this signal was observed at $25 \mathrm{kDa}$ in $\mathrm{HuH} 7 \mathrm{cT}$ since they express a FLAG-tagged core (black arrow). (B) Graphic representation of average fold changes of phospho Thr37/46 4E-BP1 normalized to 4E-BP1 (C, D) Protein lysates of HuH7 WT, cT, cNT, HuH9.13 cured and HuH9.13 were analyzed by Western blotting for the phosphorylation state of 4E-BP1 at Ser 65 and Thr 70, respectively. (E) Immunoblotting analysis of 4E-BP1 phosphorylation at Thr $37 / 46$ and the relative ratios of p4E-BP1/4E-BP1 in HuH7.5 replicon, harboring all HCV proteins. (F, G) Protein extracts of HuH7.5.1 and primary human hepatocytes infected or not with the HCV strain JFH1 were immubloted with phospho Thr37/46 4E-BP1. Fold changes of p4E-BP1 over 4E-BP1 are shown, ${ }^{*} p$ value $<0.05$. One representative immunoblot out of three independent experiments is shown and $\mathrm{p} 38$ was used as loading control. 


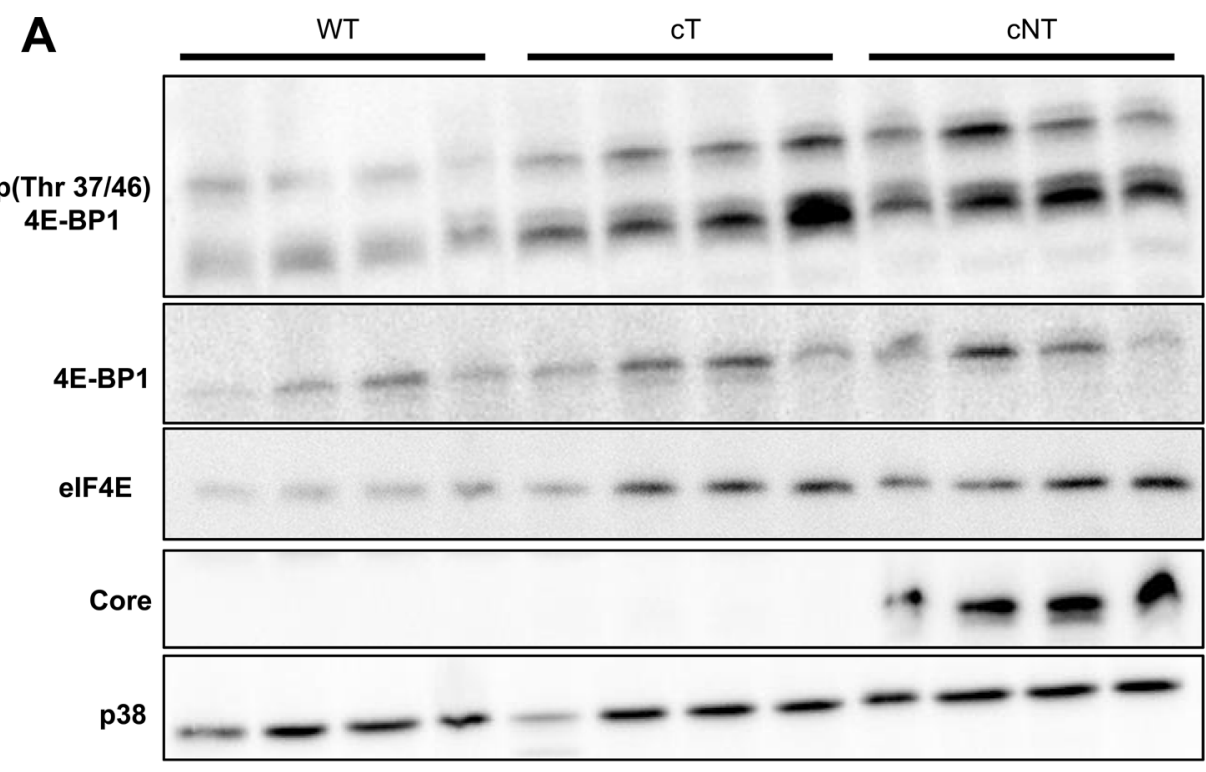

C

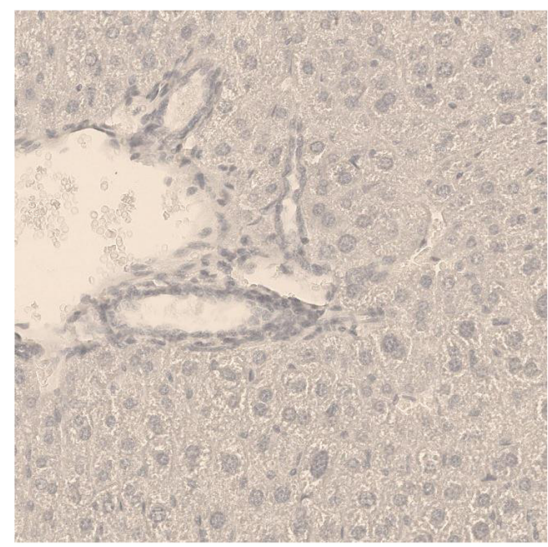

D

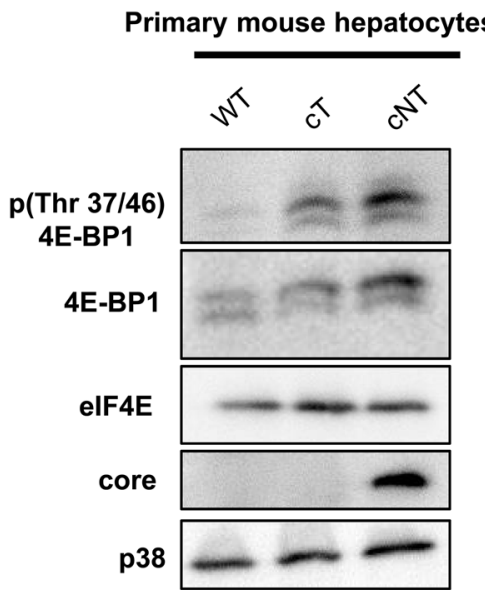

CT

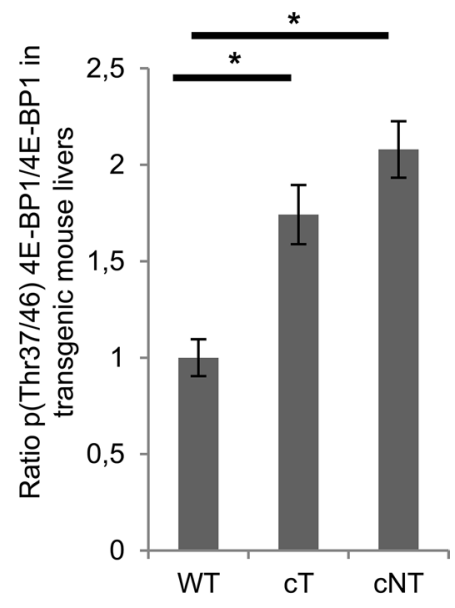

cNT
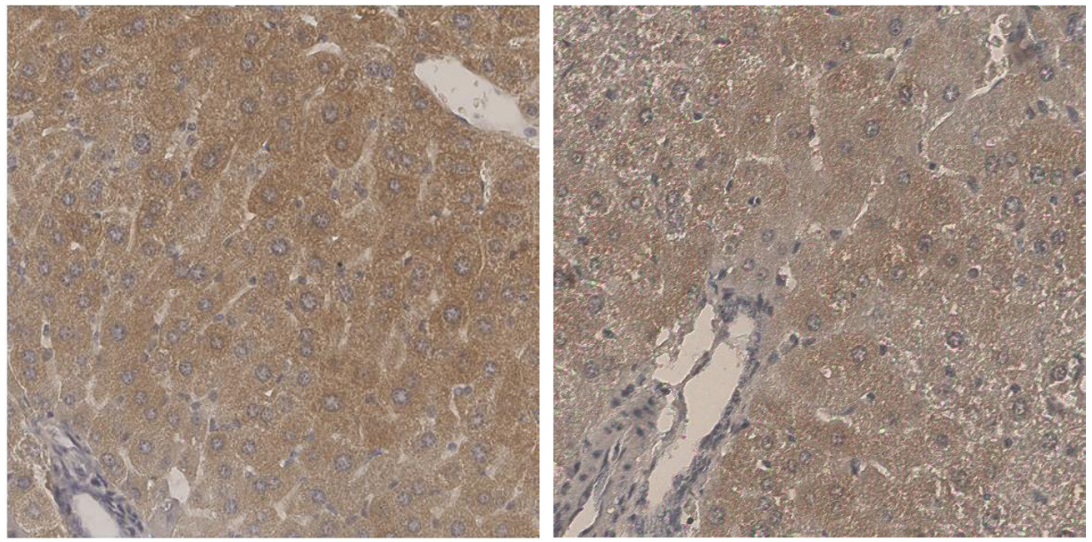

E

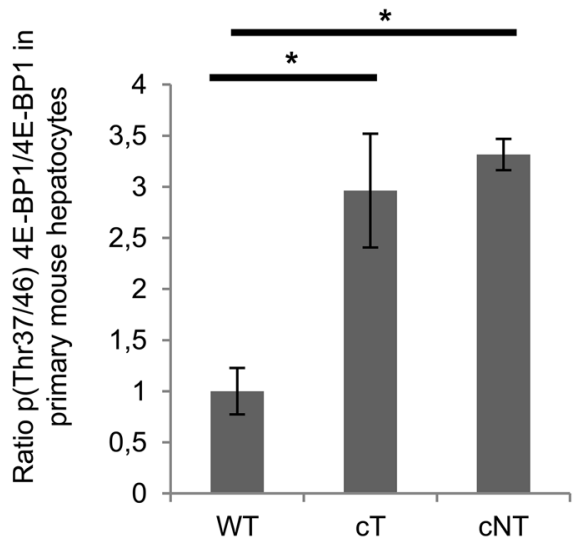

Figure 3: HCV core variants mediate 4E-BP1 phosphorylation in transgenic mouse livers. (A) Liver proteins extracted from 9-month-old WT, transgenic mice that specifically express HCV core protein isolated from tumor and non-tumor (cT or cNT) areas (4 different mice per group) were analyzed for phospho 4E-BP1 by immunoblot. (B) Quantification of phospho-4E-BP1 relative to 4E-BP1 levels, ${ }^{*} p$ value $<0.05$. (C) Immunohistochemical staining of WT, $\mathrm{cT}$ and $\mathrm{cNT}$ liver biopsies. Liver slices were immunostained with $\mathrm{p} 4 \mathrm{E}-$ BP1 antibody and representative results are shown (magnification x40). (D) Protein lysates of primary mouse hepatocytes isolated from transgenic mouse livers expressing or not $\mathrm{cT}$ and cNT were analyzed by immunoblot with antibodies directed against phospho 4E-BP1. One representative experiment is shown and p38 is used as loading control. (E) Depiction of normalized densitometric values of phospho$4 \mathrm{E}-\mathrm{BP} 1$ over 4E-BP1 in primary mouse hepatocytes, ${ }^{*} p$ value $<0.05$. 
these findings we have previously reported that another gene of this 4E-BP1 signature, vimentin was upregulated in hepatocytes expressing HCV core [4]. These data provide evidence of downstream molecular effects of 4E$\mathrm{BP} 1$ activation by $\mathrm{HCV}$ core.

\section{$\mathrm{HCV}$ core protein cooperates with Myc in hepatocarcinogenesis}

Previous reports have delineated a significant link between c-Myc and 4E-BP1 phosphorylation in Mycdriven hematological cancers [23]. Since none of the core transgenic mice had developed malignant lesions, it was therefore relevant to uncover whether HCV core turns oncogenic in a cancer predisposed atmosphere.

Hence, transgenic mice expressing either $\mathrm{HCV}$ core protein $\mathrm{cT}$ or $\mathrm{cNT}$ were intercrossed with Myc transgenic mouse lines in which liver-specific expression of c-Myc driven by woodchuck hepatitis virus (WHV) regulatory sequences causes liver cancer in all animals [24]. Liver tumors were detected earlier in bitransgenic animals carrying either $\mathrm{cT}$ or $\mathrm{cNT}$ core transgenes when compared to simple Myc littermates (Figure 5). This earlier detection was significant for Myc/cNT $(p=0.003)$ and $\mathrm{Myc} / \mathrm{cT}(p=0.045)$ as compared to Myc/WT. It was equivalent in Myc/cNT and Myc/cT mice at 9 and 12 months where all bitransgenic mice developed HCC, even though it was more pronounced in Myc/cNT in 3-monthold mice. Moreover the total number of tumors was statistically increased $(p=0.034)$ without interaction of time $(p=0.759)$ in both Myc/cT or Myc/cNT bitransgenic mice compared to Myc simple transgenic mice and no significant difference was observed between the 2 core variants $(p=0.3)$.
To correlate the marked acceleration of the onset of hepatocarcinogenesis in double transgenic mice Myc/ $\mathrm{cT}$ and $\mathrm{Myc} / \mathrm{cNT}$ to $4 \mathrm{E}-\mathrm{BP} 1$ status, further analysis of 4E-BP1 phosphorylation state in 3-month-old mouse liver extracts was performed by Western blotting. Figure $6 \mathrm{~A}$ and $6 \mathrm{~B}$ show a representative immunoblotting of 4 different mouse liver extracts per group and indicate that both $\mathrm{HCV}$ core variants triggered 4E-BP1 hyperphosphorylation in double transgenic Myc/cT and Myc/ cNT mouse livers compared to Myc/WT littermates. This finding was sustained by immunohistochemical analysis of paraffin-embedded double transgenic mouse livers using phospho-4E-BP1 (Thr37/46) (Figure 6C). A more pronounced increase in the phosphorylation level of 4E-BP1 was observed in double transgenic mice expressing both $\mathrm{HCV}$ core and Myc proteins suggesting that 4E-BP1 phosphorylation could be a possible effector of $\mathrm{HCV}$ core induced acceleration of HCC development.

Next, we sought to track 4E-BP1 phosphorylation in liver tumors, thus Western blotting assays were performed on liver extracts from double transgenic liver tumors (T) and the adjacent non-tumor tissues (NT). Since tumor detection appeared later in Myc/WT than in $\mathrm{Myc} / \mathrm{cT}$ and Myc/cNT mice, liver extract from 9-monthold mice were used to compare 4E-BP1 phosphorylation in the 3 experimental conditions. In agreement with the immunoblotting results of the upper panels, Figure 6D shows that both variants of $\mathrm{HCV}$ core significantly induced 4E-BP1 phosphorylation in NT tissues of Myc/core mouse livers as compared with Myc/WT. Furthermore, 4E-BP1 phosphorylation was more enhanced in liver tumors of all double transgenic mice when compared with nontumorous surrounding counterparts. This increased 4E-BP1 phosphorylation was also observed in the tumors

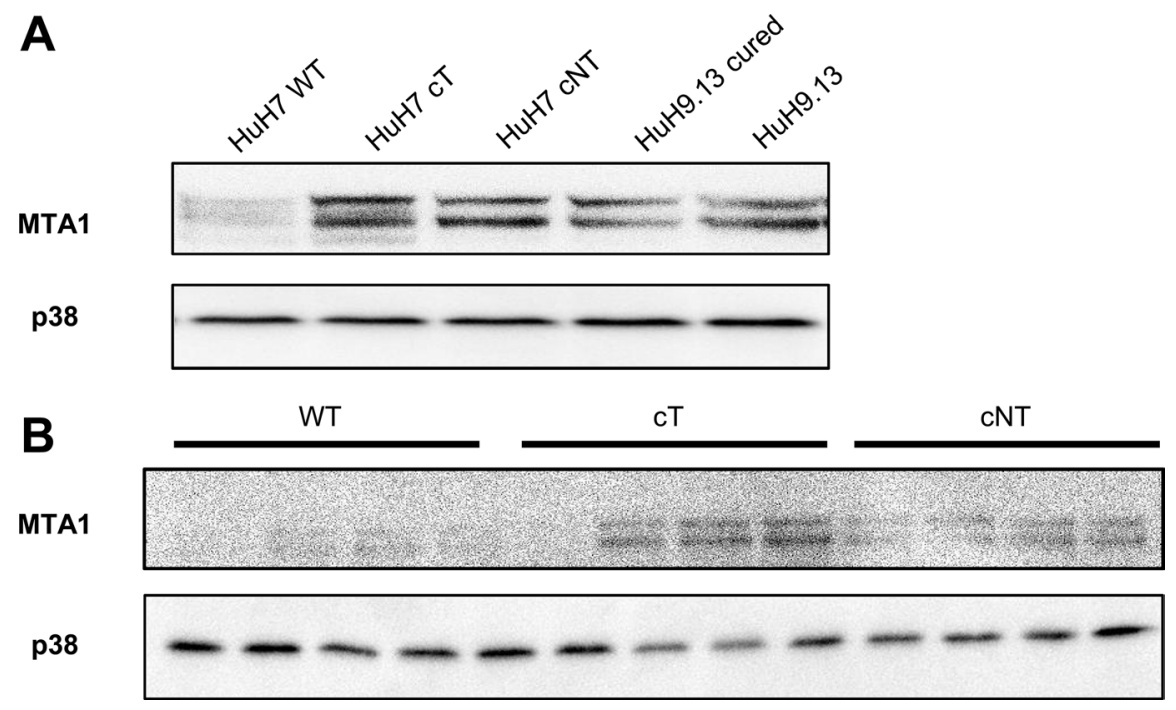

Figure 4: HCV core induces the expression of MTA1, a 4E-BP1 downstream target. (A) Immunoblotting analysis of MTA1 expression in lysates of $\mathrm{HuH} 7$ controls (WT), $\mathrm{HuH7}$ stably expressing core protein variants either isolated from tumor or non-tumor cirrhotic (cT or cNT) areas and HuH9.13 harboring the HCV NS3-NS5B subgenomic replicon and its related control (HuH9.13 cured). (B) Liver proteins extracted from 9-month-old WT, transgenic mice that specifically express HCV core protein isolated from tumor and nontumor (cT or $\mathrm{cNT}$ ) areas (4 different mice per group) were analyzed for MTA1 expression by immunoblot. 
of Myc/WT mice suggesting a role of this phosphorylation in the context of Myc-induced cancerogenesis as previously reported [23].

Altogether, the present data indicate that HCV core protein and Myc act synergistically to induce hepatic tumor development. This correlates with an enhancement of 4E-BP1 phosphorylation on Thr37 and Thr46 that might serve as a priming oncogenic event.

\section{DISCUSSION}

$\mathrm{HCV}$ core protein orchestrates a complex and dynamic interaction network with cellular proteins involved in signal transduction, transcription, nucleic acid binding, apoptosis, cell cycle, cytoskeleton and kinase activity [25]. Herein, a phosphoproteomic study was conducted to decipher the signaling pathways activated by HCV core in hepatoma cells. Most of the identified phosphorylated proteins could be clustered in the above-mentioned processes such as lipid homeostasis, cytoskeleton dynamics and interestingly translation initiation machinery. Indeed, different phosphosites identified in this phosphoproteomic study (eIF4B, 4E-BP1,
4E-BP2) are parts of different eukaryotic initiation factors that govern translational machinery. 4E-BP1 represents a master regulator of protein synthesis control that is often deregulated in cancer cells. It was reported that activation of the 4E-BP1/eIF4E axis selectively stimulates the expression of malignancy-related mRNAs [26] and phosphorylation of 4E-BP1 enables cancer cell survival by enhancing protein synthesis capacity. Validation of phosphoproteomic data by immunoblotting indicated that indeed, phosphorylation levels of 4E-BP1 were increased in $\mathrm{HuH7}$ cells, primary mouse hepatocytes expressing either HCV cT or cNT core proteins and in HuH7.5.1 cells and primary human hepatocytes infected with the $\mathrm{HCV}$ strain JFH1. The same results were obtained when total livers of HCV cT or $\mathrm{cNT}$ transgenic mice were examined indicating that $\mathrm{HCV}$ core influences the phosphorylation status of 4E-BP1 in vivo. Increased expression of MTA1 in $\mathrm{HuH7}$ or mouse livers expressing HCV cores supports the notion that core-induced 4E-BP1 phosphorylation leads to activation of at least some of 4E-BP1downstream targets.

Both cT and cNT variants exhibit the same capacity to increase the phosphorylation of $4 \mathrm{E}-\mathrm{BP} 1$. However, it is interesting to note that the core $\mathrm{cT}$ is less expressed
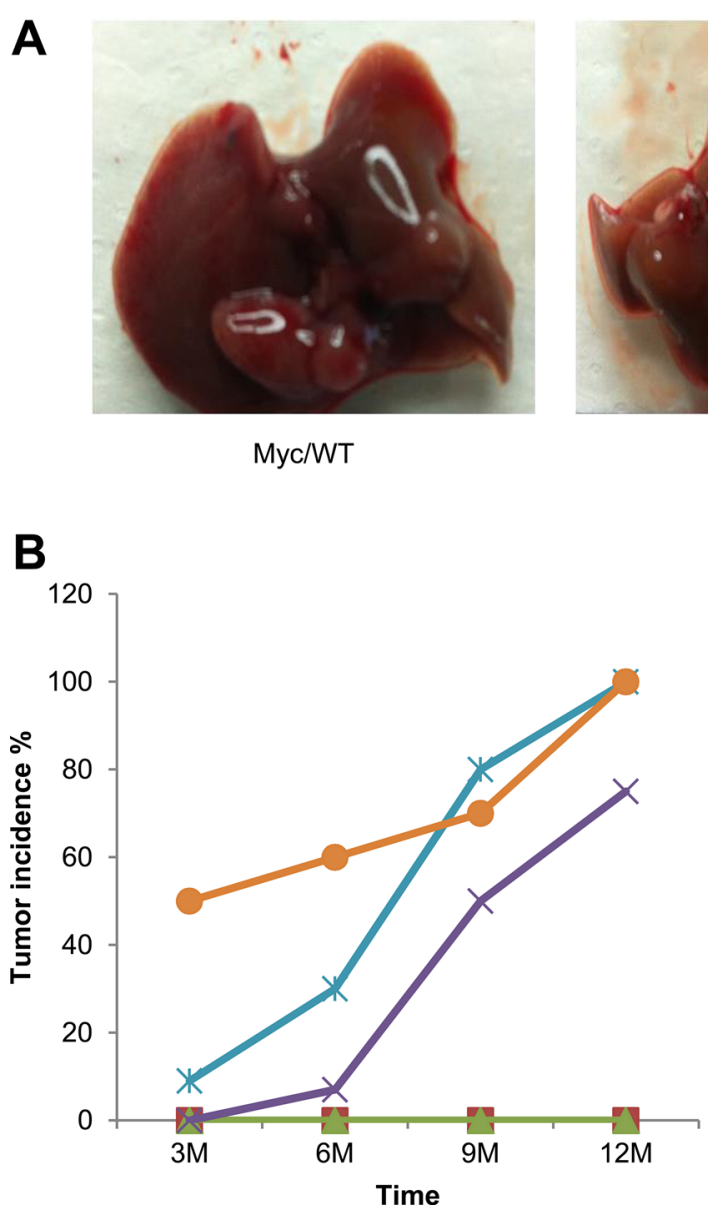
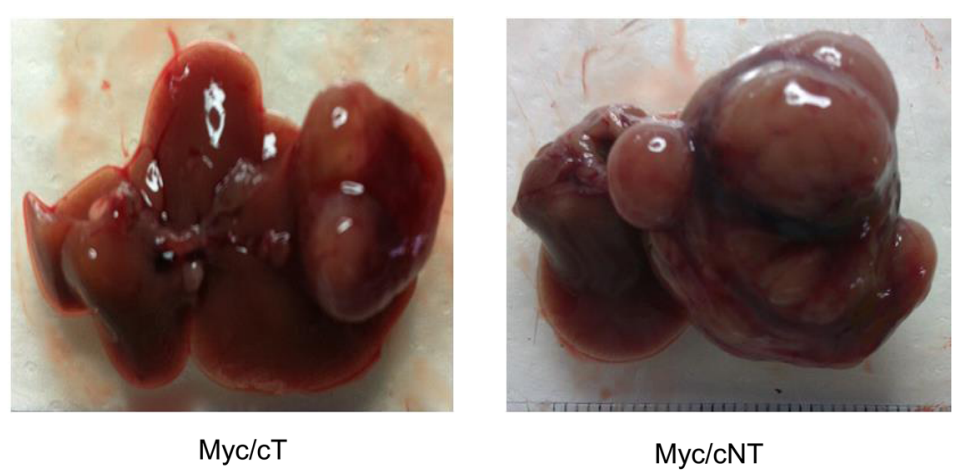

$\mathrm{Myc} / \mathrm{cNT}$

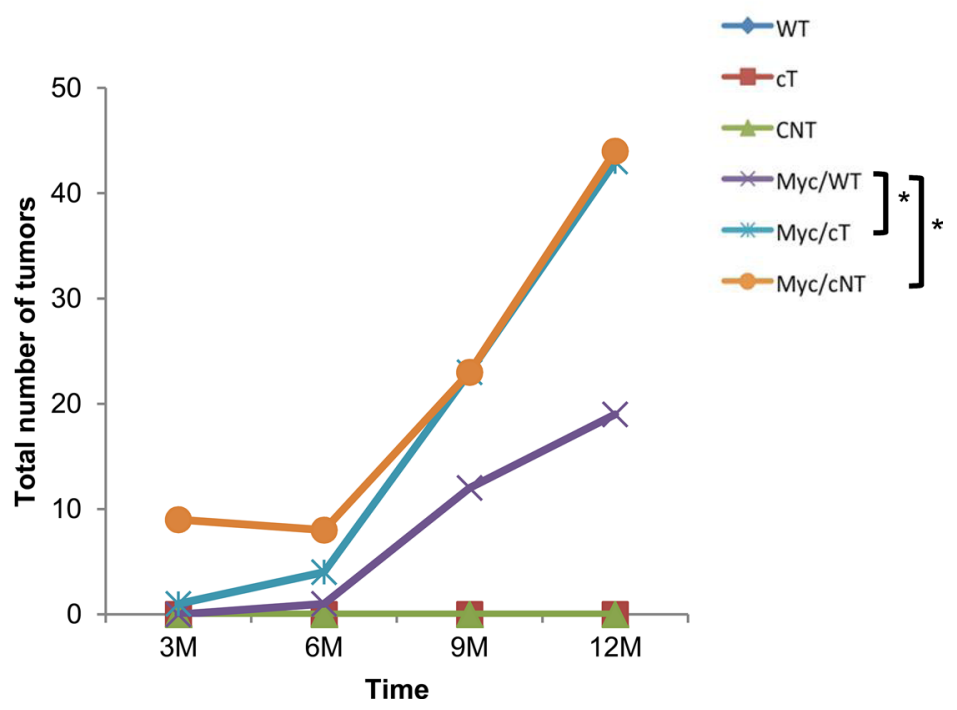

Figure 5: HCV core protein accelerates Myc-induced carcinogenesis in double transgenic mice. (A) Gross images of Myc/ WT, Myc/cT and Myc/cNT transgenic mouse livers. (B) Graphical representation of the percentage of tumor incidence and the total number of tumors in all transgenic mouse groups at 3, 6, 9 and 12 months, ${ }^{*} p$ value $<0.05$. 
than $\mathrm{cNT}$ in all cell lines tested and that the $\mathrm{cT}$ protein expression is barely detected in vivo reflecting the expression level which is observed in infected human tissues. This implies that a weak expression of the cT is as effective as the highly expressed cNT, underlying the importance of core genetic variability and expression in mediating downstream responses.

The important finding of this study lies in the significant potentiation of tumor development when $\mathrm{HCV}$ core is expressed in oncogenic context. Indeed, the onset
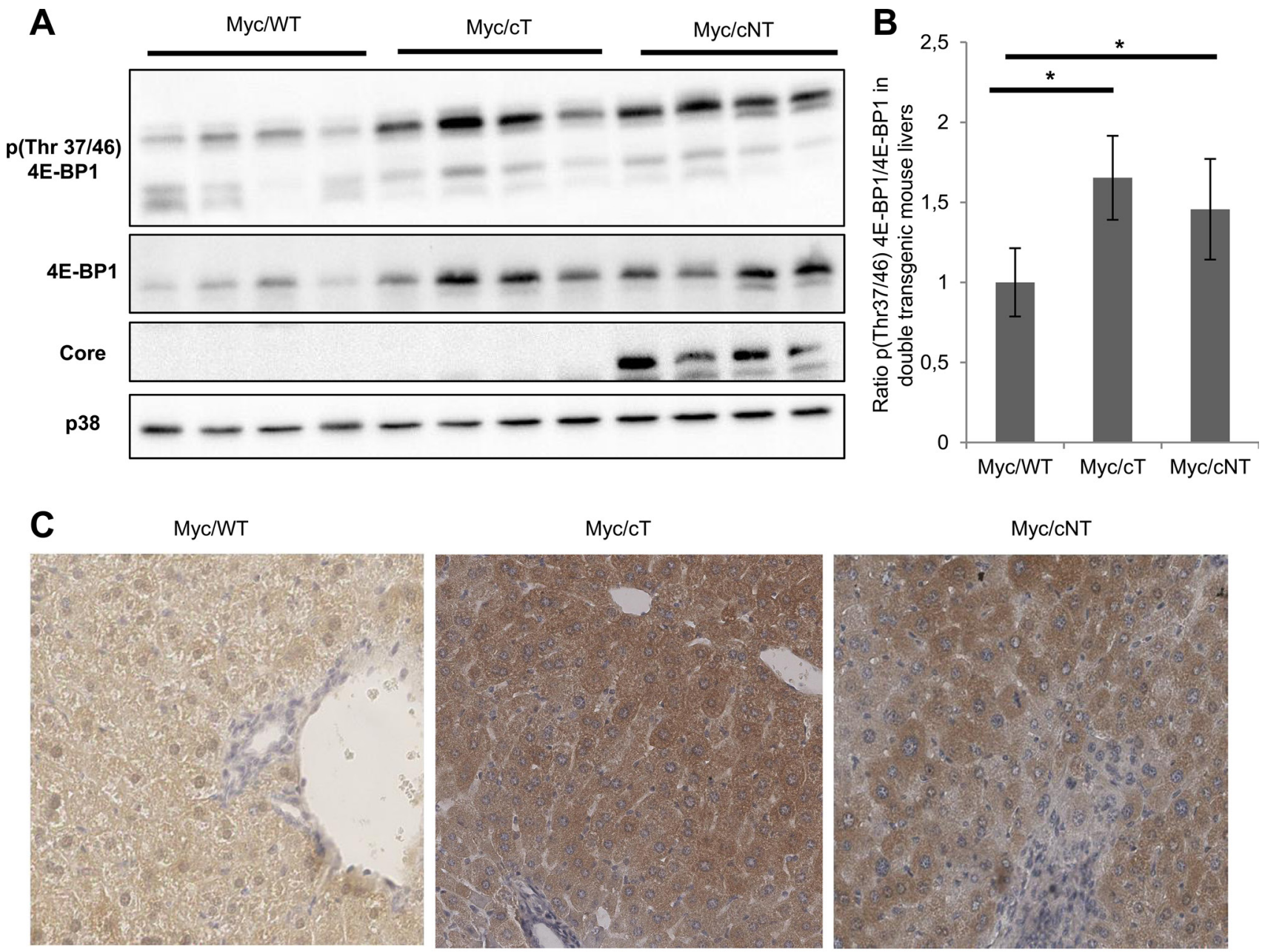

D

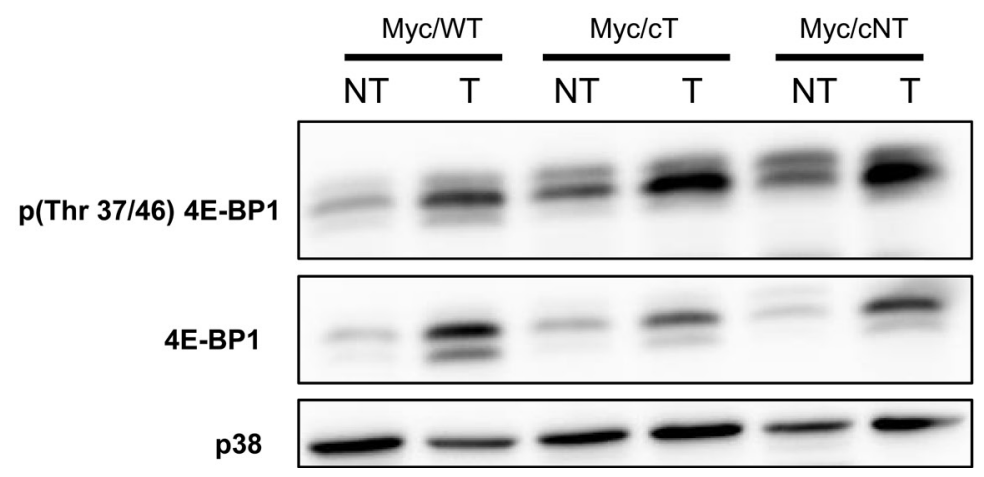

Figure 6: HCV core increases 4E-BP1 phosphorylation level in Myc/cT and Myc/cNT mouse livers. (A) Representative immunoblotting assay of phospho 4E-BP1 on proteins extracted from livers of 3-month-old simple Myc/WT or double transgenic, Myc/cT and Myc/cNT mice (4 different mice/group). (B) Average fold changes of densitometric values of phospho Thr37/46 4E-BP1 expression relative to 4E-BP1 levels are represented graphically, ${ }^{*} p$ value $<0.05$. (C) Immunohistochemical analysis of tissue slices from paraffinembedded livers of simple Myc/WT or double transgenic mice, Myc/cT and Myc/cNT, using phospho-4E-BP1 (magnification x40). (D) Protein extracts from double transgenic liver tumors (T) and the adjacent non-tumor tissues (NT) of 9-month-old Myc/WT, Myc/cT and $\mathrm{Myc} / \mathrm{cNT}$ were analyzed for phospho-4E-BP1. One representative immunoblot of three independent experiments is shown, p38 is used as loading control. 
and the higher number of tumors were observed in Myc/ $\mathrm{HCV}$ core double transgenic mice when compared to single Myc littermates. Thus, cooperation with a cellular oncogene was required to reveal the oncogenicity of $\mathrm{HCV}$ core, since no malignancy was observed in our simple transgenic animal models. This novel function of HCV core acting as Myc tumor promoter in liver tumorigenesis is in accordance with the assumption that $\mathrm{HCV}$ core is a tumor accelerator in chemically induced HCC in DEN treated transgenic mice $[27,28]$.

Although many reports associated the 4E-BP1/ eIF4E axis to the development of different cancers, 4E-BP1 phosphorylation in $\mathrm{HCV}$ core transgenic mice was not sufficient to initiate carcinogenesis and thus subsequent oncogenic alterations were required to drive oncogenesis. This is consistent with the obtained results in $\mathrm{HCV}$ core/Myc double transgenic mice. In accordance with our results, it was recently reported that activation of the 4E-BP1/eIF4E axis alone was not able to promote malignant transformation of murine hepatocytes, but that eIF4E cooperates with activated $\mathrm{N}$-Ras to induce liver tumor development in mice [19]. Furthermore, in a E $\mu$-Myc transgenic mouse model in which constitutive overexpression of Myc in the B-cell compartment drives lymphomagenesis, it was reported that Myc overexpression results in 4E-BP1 hyperphosphorylation that was maintained during tumor progression and was required for cancer cell survival in Myc-dependent tumor initiation and maintenance [23]. Moreover the 4E-BP1/eIF4E axis was reported as a key event in Myc lymphomagenesis since 4E-BP1dependent inhibition of eIF4E activity impedes Mycdriven lymphomas [29]. In our model, 4E-BP1 was found to be hardly phosphorylated in non-tumor tissues from Myc/WT mice, but this phosphorylation level was greatly increased in tumor tissue. This is consistent with the findings that in WHV/Myc transgenic mice, Myc is transiently overexpressed in the liver after birth, and it is re-expressed at tumor onset [24]. More importantly, phosphorylated 4E-BP1 abundance was observed in non-tumor tissue of $\mathrm{Myc} / \mathrm{cT}$ and $\mathrm{Myc} /$ $\mathrm{cNT}$ double transgenic and this phosphorylation was more pronounced in the tumors. It must be noted that, although in these transgenic mice the ratio between p4E-BP1/4E-BP1 was statistically significant, the total forms of 4E-BP1 were increased as compared to control mouse livers. Thus, as 4E-BP1 has been reported to be upregulated in many cancers it is possible that the non phosphorylated form plays also a role in the development of Myc-induced HCC.

Altogether our data clearly establish that 4E-BP1 expression and phosphorylation are important targets for HCV core-related effects. Furthermore this study reinforces the notion that $\mathrm{HCV}$ core may potentiate oncogenes by acting as a cooperating partner, in particular in c-Myc-induced liver carcinogenesis.

\section{MATERIALS AND METHODS}

\section{Reagents}

Antibodies: 4E-BP1 (9452), phospho(Thr37/46) 4E-BP1 (2855), phospho(Ser65) 4E-BP1 (9451), phospho(Thr70) 4E-BP1 (9455), p44/42-MAPK (9102), phospho(Thr202/Tyr204) p44/42-MAPK (9101) and MTA1 (5647) were purchased from Cell Signaling, Core (sc-52403) and p38 (C-20, sc-535) provided from Santa Cruz. NS5A (ab13833) was from Abcam. Inhibitors: Rapamycin (9904) and PD0325901 (PZ0162) were purchased from Cell Signaling and Sigma, respectively.

\section{Transgenic mice}

$\mathrm{HCV}$ core and WHV/c-Myc transgenic mice [24] were maintained in a pathogen-free facility, fed, and monitored in agreement with protocols approved by the guidelines of the Ministère de l'Agriculture (France). WHV/c-Myc transgenic mice, in which liver-specific expression of c-Myc is driven by woodchuck hepatitis virus (WHV) regulatory sequences, were previously described [24]. To establish HCV core transgenic mice, genotype $1 \mathrm{~b}$ core cDNAs isolated from tumor $(\mathrm{T})$ or cirrhotic nodules (NT) from the same patient were cloned downstream of hepatitis B virus regulatory element and microinjected into mouse embryos from the C57BL/6 (Institut Clinique de la Souris, Strasbourg, France). Both $\mathrm{HCV}$ core sequences, $\mathrm{cT}$ and $\mathrm{cNT}$, were verified and correspond to previously published ones [3].

Homozygotes WHV/c-Myc transgenic mice were crossed with either homozygotes core T, core NT or C57BL/6 mice. The F1 were identified by hybridization of tail cDNA with WHV c-Myc and core probes. At least 10 mice per group were analyzed. Since it was previously shown that HCC development was more prominent in males, only males were selected in this study.

Double and single transgenic mice were euthanized at 3, 6, 9 or 12 months and livers were examined for tumor size and number. Tumor samples and adjacent liver tissues were fixed in $4 \%$ paraformaldehyde and embedded in paraffin for histopathological examination. For protein analysis, tumor samples were dissected free of adjacent liver tissues, capsule and necrosis, snap-frozen in liquid nitrogen and kept at $-80^{\circ} \mathrm{C}$. Livers from nontransgenic C57BL/6, mice were used as controls.

\section{Cell culture and viral infection}

The hepatoma cell line $\mathrm{HuH} 7$ was obtained from ATCC. HuH7 cT and HuH7 cNT cells stably express $\mathrm{HCV}$ core protein variants isolated from tumor or nontumor cirrhotic areas, respectively. HuH7.5 replicon cells express all HCV proteins. HuH9.13 cell line harbors the HCV NS3-NS5B subgenomic replicon. HuH9.13 
cured cell line was obtained from HuH9.13 after 1month treatment with $500 \mathrm{U} / \mathrm{ml}$ interferon $\alpha 2 \mathrm{a}$ as described [30]. HuH7.5.1 cells were gift from F.V. Chisari, the Scripps Research Institute, La Jolla, CA, USA [31]. All cell lines were cultured in Dulbecco's Modified Eagle's Medium (DMEM) supplemented with 10\% fetal bovine serum and penicillin/streptomycin at $37^{\circ} \mathrm{C}$ in a humidified $5 \% \mathrm{CO}_{2}$ atmosphere.

Primary hepatocytes of HCV core transgenic mice were isolated by in situ collagenase perfusion of livers as previously described [4].

Human primary hepatocytes freshly isolated from HCV-seronegative adult patients were purchased from Biopredic (Rennes, France) and maintained in primary culture at $37^{\circ} \mathrm{C}$ in a humidified $5 \% \mathrm{CO}_{2}$ atmosphere as described previously [32]. Briefly, primary human hepatocytes were resuspended in complete medium consisting of Leibovitz's L-15 medium (Invitrogen, Cergy Pontoise, France) supplemented with $26 \mathrm{mM} \mathrm{NaHCO}$, $100 \mu \mathrm{g} / \mathrm{ml}$ streptomycin, $100 \mathrm{U} / \mathrm{ml}$ penicillin, $100 \mathrm{IU} / 1$ insulin (Novo Nordisk, Bagsvaerd, Denmark) and 10\% heat-inactivated FCS, and seeded onto 6-well plates precoated with calf skin type I collagen (Sigma-Aldrich) at a density of $1.6 \times 10^{5}$ viable cells $/ \mathrm{cm}^{2}$. The medium was replaced $16 \mathrm{~h}$ later with fresh complete medium supplemented with $1 \mu \mathrm{M}$ hydrocortisone hemisuccinate (SERB, Paris, France), and cells were left in this medium until HCV inoculation 2 days later. A high-titre stock of JFH1-HCV [33] was produced as described previously [32]. HuH7.5.1 cells and primary human hepatocytes were inoculated at a multiplicity of infection of 0.2 and 2 , respectively. The culture medium was replaced with the inoculum diluted in the smallest volume of fresh medium sufficient for covering the cells. The inoculum was removed after a 4-hour incubation, then cells were washed 3 times with phosphate-buffered saline and maintained in their respective complete medium for 3 (HuH7.5.1 cells) or 6 (primary human hepatocytes) days before lysis for Western blot analysis.

\section{Stable isotope labelling with aminoacids in cell culture and phosphopeptide enrichment}

Metabolic labelling was performed using the SILAC approach where $\mathrm{HuH7}$ cells, or $\mathrm{HuH7}$ cells stably expressing $\mathrm{HCV}$ cT protein were cultured either in light, medium or heavy SILAC media. Inversion of SILAC labeling allowed us to compare three independent experiments while avoiding possible labeling biases. Cells were cultured in DMEM supplemented with $10 \%$ dialyzed fetal bovine serum, $50 \mathrm{mg}$ 1-proline, and either 1-arginine (Arg0) and 1-lysine (Lys0) (light medium), or ${ }^{13} \mathrm{C}_{6}{ }^{14} \mathrm{~N}_{4}-1-$ arginine (Arg6) and 4,4,5,5-- $\mathrm{D}_{4}$-1-lysine (Lys4) (medium medium), or ${ }^{13} \mathrm{C}_{6}{ }^{15} \mathrm{~N}_{4}$-1-arginine (Arg10) and ${ }^{13} \mathrm{C}_{6}{ }^{15} \mathrm{~N}_{2}-1-$ Lysine (Lys8) (heavy medium) (Thermo Scientific). Cells were maintained in culture for at least five doublings and the efficiency of labeling was confirmed by MS/MS analysis.

Whole cell protein extracts were obtained by lysing cells in a RIPA lysis buffer containing $50 \mathrm{mM}$ Tris$\mathrm{HCl} \mathrm{pH} 7.4,1 \% \mathrm{NP}-40,150 \mathrm{mM} \mathrm{NaCl}, 0.25 \%$ sodium deoxycholate, $0.5 \%$ SDS, Benzon nuclease (Novagen), a protease inhibitor cocktail and phosphatase inhibitors (Roche). Total cellular protein extracts were precipitated with TCA/acetone and then resuspended in $8 \mathrm{M}$ urea in $100 \mathrm{mM}$ triethylammonium bicarbonate (TEAB) $\mathrm{pH}$ 8.5. A Bradford assay was performed to equalize protein concentrations for subsequent 1:1:1 ratio mixing of the three lysates. Mixed lysates were reduced by $10 \mathrm{mM}$ Tris (2-carboxyethyl)phosphine (TCEP) for $1 \mathrm{~h}$ at $37^{\circ} \mathrm{C}$ and then alkylated by $20 \mathrm{mM}$ methylmethanethiosulfonate (MMTS) for $30 \mathrm{~min}$ at room temperature. After 7-fold dilution in $100 \mathrm{mM} \mathrm{TEAB}$, proteins were digested overnight with sequencing grade trypsin (Promega) at an enzyme/protein ratio of $1 / 100(\mathrm{w} / \mathrm{w})$ at $37^{\circ} \mathrm{C}$. The total peptide mixtures were then acidified to $\sim \mathrm{pH} 3$ using acetic acid (AA), desalted on a C18 spin columns (Harvard Apparatus) and eluted in 60\% ACN, 3\% AA. This eluate was diluted 1:1 with water to reach a composition of $30 \% \mathrm{ACN}, 1.5 \% \mathrm{AA}$, compatible with phosphopeptide enrichment. Desalted peptides were enriched for phosphopeptides by incubation with $10 \mathrm{uL}$ of packed IMAC beads (Sigma-Aldrich) for $2 \mathrm{~h}$ on a wheel rotating at $15 \mathrm{rpm}$. After washing the beads three times with $30 \%$ ACN, 1.5\% AA, phosphopeptides were eluted from the IMAC resin using the alkaline buffer $400 \mathrm{mM}$ $\mathrm{NH}_{4} \mathrm{OH}$. Eluates were neutralized with $10 \% \mathrm{AA}$ and dried by vacuum centrifugation [34]. Finally, phosphopeptides were resuspended in 5\% ACN, $0.1 \%$ formic acid (FA) for subsequent analysis by LC-MS/MS.

\section{Liquid chromatography and mass spectrometry}

Phosphopeptide separation was performed on an Ultimate 3000 nano LC system (Dionex) equipped with a C18 column (Acclaim PepMap C18, $75 \mu \mathrm{m}$ id $\times 15$ cm length, $3 \mu \mathrm{m}$ particle size, $100 \AA$ porosity, Dionex) and online connected to an LTQ Orbitrap XL mass spectrometer equipped with an ETD (Electron Transfer Dissociation) module (Thermo-Fisher Scientific). The mobile phases consisted of solvents $\mathrm{A}=5 \% \mathrm{ACN}(\mathrm{v} / \mathrm{v})$, $0.1 \% \mathrm{FA}(\mathrm{v} / \mathrm{v})$ in water and $\mathrm{B}=80 \% \mathrm{ACN}(\mathrm{v} / \mathrm{v}), 0.1 \%$ FA (v/v) in water. Phosphopeptides were separated at a flow rate of $0.3 \mu \mathrm{L} / \mathrm{min}$ using a linear gradient of $60 \mathrm{~min}$ ramping from 0 to $50 \%$ of solvent $\mathrm{B}$ followed by an increase to $100 \%$ of solvent B in $10 \mathrm{~min}$. The column was finally washed with $100 \%$ of solvent $B$ for $10 \mathrm{~min}$ followed by re-equilibration with solvent $\mathrm{A}$ for $30 \mathrm{~min}$.

Column eluent was sprayed into the MS instrument operated with a lock mass of 445.1200 for more accurate mass measurements in FTMS mode. Survey spectra were acquired over the mass range $\mathrm{m} / \mathrm{z} 400-1400$ at a 
resolution of 30,000 in the Orbitrap cell. In two separate runs, MS/MS data were acquired in data-dependent mode by selecting from the FTMS spectra the six most intense precursor ions for fragmentation by collision induced dissociation (CID) or electron transfer dissociation (ETD). Former target ions selected for $\mathrm{MS}^{2}$, within a mass window of $+/-5 \mathrm{ppm}$, were dynamically excluded for 45s. In CID fragmentation mode, Multistage Activation (MSA) was applied, while considering the possible neutral losses of $32.67,49.00,65.33$ and 98.00 to account for singly and doubly phosphorylated peptides [35]. In CID, only species of charge states $2+$ and $3+$ were selected for fragmentation; in ETD, those of charge states 2+ and above were selected. For ETD, fluoranthene was used as the electron donor. A supplemental activation was systematically applied at $20 \%$ to increase fragmentation efficiency. Peptides were fragmented after accumulating ions to a target value of $2.10^{5}$, with a maximum injection time of $500 \mathrm{~ms}$ and using a charge state dependent reaction time (following the formula: RT $=100 \mathrm{~ms} \times 2 / \mathrm{z}$, with $\mathrm{z}$ the precursor charge state).

\section{Assigning peptide sequences to MS/MS spectra and relative quantification}

Raw spectra were searched against the human SwissProt protein database (released on July 30th 2013) using the Andromeda search engine implemented in the MaxQuant software (version 1.3.0.5) that includes features for SILAC-based quantitation and phosphosite localization. The SILAC label modifications and methylthio $(C)$ for cysteine residues were set as fixed modifications in the database search. Methionine oxidation and phosphorylation on $\mathrm{S}, \mathrm{T}$ and $\mathrm{Y}$ residues were added as variable modifications. The precursor and fragment ion mass tolerances were 5 ppm and 0.6 $\mathrm{Da}$, respectively. Up to two missed cleavages were allowed for trypsin digestion and the false discovery rate (FDR) was set to $1 \%$ for both peptide and protein identifications.

High precision SILAC-based quantitation of proteins was achieved by MaxQuant in a fully automatic way. Peaks are detected in each MS scan, peptide hills over the $\mathrm{m} / \mathrm{z}$-retention time are taken into account for intensity integrations and ratio calculation.

Phosphorylation site localization was based on PTM scores [36] that assign probabilities for each possible amino acid and then allow grouping the phosphosites into three categories. Probability scores greater or equal to 0.75 were considered to allow definite phosphosite localization, scores smaller than 0.75 and greater or equal to 0.5 corresponded to ambiguously localized phosphosites, whereas scores smaller than 0.5 were indicated non-localized phosphosites. This proteomic approach applied to the cellular models in three independent SILAC experiments led to the identification of 1308 phosphopeptides differing by their amino acid sequence corresponding to an overall of 977 different proteins. Phosphopeptides showing abundance ratios core/WT greater than 1.96 standard deviations distant from the mean in at least two out of the three biological experiments, were considered to be significantly hyperphosphorylated.

\section{Western blot analysis}

Protein extracts were subjected to SDS-PAGE gels and transferred onto nitrocellulose membranes. The blots were probed with different antibodies according to the manufacturer's instructions. Experiments were repeated three times and signal quantification was performed using Genetools software.

\section{Immunohistochemistry}

Immunohistochemical staining on mouse liver slices was performed on $4 \%$ paraformaldehydefixed, paraffin-embedded tissues. Deparaffinized sections were incubated in 3\% hydrogen peroxide for 20 minutes to quench the endogenous peroxidase. For antigen retrieval, slides were treated in citrate buffer for 10 minutes and incubated overnight with rabbit phospho(Thr37/46) 4E-BP1 at 1/1500 dilution in PBS, followed by an incubation with HRP-labeled secondary antibody (Dako Envision Systems) for 30 minutes. Immunoperoxidase staining was carried out with diaminobenzidine.

\section{Statistical analysis}

The total number of tumors was analyzed by a Fisher test using a 2-way ANOVA: variance analysis integrated 2 factors (time and transgenic mouse group). Interaction between these 2 factors was excluded on the basis of Myc/WT control mice. LSD (post Hoc) test was performed after Fisher test to discriminate significance of each capsid group as compared to controls Myc/WT. Comparisons between two groups were performed with $t$ test, $(*) p$ value $<0.05$.

\section{Quantitative RT-PCR}

Frozen liver tissues were homogenized using Precellys (Ozyme) in cell-lysis grinding buffer and total RNA was isolated using RNAeasy kit (Qiagen), according to the manufacturer's instructions. Total RNAs were subjected to RNase-free DNase (Ambion) and converted into cDNA by using a Revert Aid Premium First Strand (Fermentas) and qPCR with Light Cycler Fast Start DNA green master (Roche Diagnostics). HPRT was used as housekeeping gene and relative quantification was based on the $2^{-\Delta \Delta C T}$ method . 


\section{ACKNOWLEDGMENTS}

We thank Charles Rice for HuH7.5 and FL/neo replicon cells, Ralf Bartenschlager for HuH9.13 cells and Francis Chisari for HuH7.5.1 cells. We acknowledge René Duchateau at Service des Animaux Transgéniques (SEAT) for animal breedings. We are grateful to Florence Petit, Véronique Legros and Taous Ait Saadi for technical contribution. We acknowledge François Guillonneau, Patrick Mayeux, France Demaugre and Marie-Annick Buendia for helpful discussions.

\section{CONFLICTS OF INTEREST}

All authors have nothing to disclose.

\section{FINANCIAL SUPPORT}

This work was supported by core funding from Université Paris-Sud and Institut National de la Santé et la Recherche Médicale (INSERM). Grants were obtained from l'Agence Nationale de Recherche sur le SIDA et les hépatites virales (ANRS), le comité Yvelines et le comité Ile de France de la Ligue Nationale Contre le Cancer and l'Institut National du Cancer (INCa, PAIR-CHC). The Orbitrap XL-ETD instrument was funded by CNRS, Genopole-France, Institut National de la Recherche Agronomique, Université d'Evry Val d'Essonne, Région Ile-de-France and the Agence Nationale de la Recherche (ANR). CA was recipient of a grant from PRES UniverSud-Paris and ANRS, CL of a grant from INCa.

\section{REFERENCES}

1. Forner A, Llovet JM, Bruix J. Hepatocellular carcinoma. Lancet. 2012; 379:1245-55.

2. Rozenblatt-Rosen $\mathrm{O}$, Deo RC, Padi M, Adelmant G, Calderwood MA, Rolland T, Grace M, Dricot A, Askenazi M, Tavares M, Pevzner SJ, Abderazzaq F, Byrdsong D, et al. Interpreting cancer genomes using systematic host network perturbations by tumour virus proteins. Nature. 2012; 487:491-5.

3. Pavio N, Battaglia S, Boucreux D, Arnulf B, Sobesky R, Hermine $\mathrm{O}$, Bréchot C. Hepatitis $\mathrm{C}$ virus core variants isolated from liver tumor but not from adjacent nontumor tissue interact with Smad3 and inhibit the TGF-beta pathway. Oncogene. 2005; 24:6119-32.

4. Battaglia S, Benzoubir N, Nobilet S, Charneau P, Samuel D, Zignego AL, Atfi A, Bréchot C, Bourgeade MF. Liver cancer-derived hepatitis $\mathrm{C}$ virus core proteins shift TGFbeta responses from tumor suppression to epithelialmesenchymal transition. PLoS One. 2009; 4:e4355.

5. Pasquinelli C, Shoenberger JM, Chung J, Chang KM, Guidotti LG, Selby M, Berger K, Lesniewski R, Houghton M, Chisari FV. Hepatitis C virus core and E2 protein expression in transgenic mice. Hepatology. 1997; 25:719-27.

6. Moriya K, Yotsuyanagi H, Shintani Y, Fujie H, Ishibashi K, Matsuura Y, Miyamura T, Koike K. Hepatitis C virus core protein induces hepatic steatosis in transgenic mice. J Gen Virol. 1997; $78: 1527-31$.

7. Perlemuter G, Sabile A, Letteron P, Vona G, Topilco A, Chrétien Y, Koike K, Pessayre D, Chapman J, Barba G, Bréchot C. Hepatitis C virus core protein inhibits microsomal triglyceride transfer protein activity and very low density lipoprotein secretion: a model of viral-related steatosis. FASEB J. 2002; 16:185-94.

8. Kawaguchi T, Yoshida T, Harada M, Hisamoto T, Nagao Y, Ide T, Taniguchi E, Kumemura H, Hanada S, Maeyama M, Baba S, Koga H, Kumashiro R, et al. Hepatitis C virus down-regulates insulin receptor substrates 1 and 2 through up-regulation of suppressor of cytokine signaling 3. Am J Pathol. 2004; 165:1499-508.

9. Shintani Y, Fujie H, Miyoshi H, Tsutsumi T, Tsukamoto K, Kimura S, Moriya K, Koike K. Hepatitis C virus infection and diabetes: direct involvement of the virus in the development of insulin resistance. Gastroenterology. 2004; 126:840-8

10. Honda A, Hatano M, Kohara M, Arai Y, Hartatik T, Moriyama T, Imawari M, Koike K, Yokosuka O, Shimotohno K, Tokuhisa T. HCV-core protein accelerates recovery from the insensitivity of liver cells to Fas-mediated apoptosis induced by an injection of anti-Fas antibody in mice. J Hepatol. 2000; 33:440-7.

11. Benali-Furet NL, Chami M, Houel L, De Giorgi F, Vernejoul F, Lagorce D, Buscail L, Bartenschlager R, Ichas F, Rizzuto R, Paterlini-Bréchot P. Hepatitis $\mathrm{C}$ virus core triggers apoptosis in liver cells by inducing ER stress and ER calcium depletion. Oncogene. 2005; 24:4921-33.

12. Moriya K, Fujie H, Shintani Y, Yotsuyanagi H, Tsutsumi T, Ishibashi K, Matsuura Y, Kimura S, Miyamura T, Koike K. The core protein of hepatitis $\mathrm{C}$ virus induces hepatocellular carcinoma in transgenic mice. Nat Med. 1998; 4:1065-7.

13. Klopstock N, Katzenellenbogen M, Pappo O, SklairLevy M, Olam D, Mizrahi L, Potikha T, Galun E, Goldenberg D. HCV tumor promoting effect is dependent on host genetic background. PLoS One. 2009; 4:e5025.

14. Brunn GJ, Fadden P, Haystead TA, Lawrence JC Jr. The mammalian target of rapamycin phosphorylates sites having a (Ser/Thr)-Pro motif and is activated by antibodies to a region near its $\mathrm{COOH}$ terminus. J Biol Chem. 1997; 272:32547-50.

15. Pearson G, Robinson F, Beers Gibson T, Xu BE, Karandikar M, Berman K, Cobb MH. Mitogenactivated protein (MAP) kinase pathways: regulation and physiological functions. Endocr Rev. 2001; 22:153-83.

16. Heesom KJ, Denton RM. Dissociation of the eukaryotic initiation factor-4E/4E-BP1 complex involves phosphorylation of 4E-BP1 by an mTOR-associated kinase. FEBS Lett. 1999; 457:489-93. 
17. Gingras AC, Raught B, Gygi SP, Niedzwiecka A, Miron M, Burley SK, Polakiewicz RD, Wyslouch-Cieszynska A, Aebersold R, Sonenberg N. Hierarchical phosphorylation of the translation inhibitor 4E-BP1. Genes Dev. 2001; 15:2852-64.

18. Elia A, Constantinou C, Clemens MJ. Effects of protein phosphorylation on ubiquitination and stability of the translational inhibitor protein 4E-BP1. Oncogene. 2008; 27:811-22.

19. Wang C, Cigliano A, Jiang L, Li X, Fan B, Pilo MG, Liu Y, Gui B, Sini M, Smith JW, Dombrowski F, Calvisi DF, Evert M, et al. 4EBP1/eIF4E and p70S6K/RPS6 axes play critical and distinct roles in hepatocarcinogenesis driven by AKT and N-Ras proto-oncogenes in mice. Hepatology. 2015; 61:200-13.

20. George A, Panda S, Kudmulwar D, Chhatbar SP, Nayak SC, Krishnan HH. Hepatitis C virus NS5A binds to the mRNA cap-binding eukaryotic translation initiation $4 \mathrm{~F}$ (eIF4F) complex and up-regulates host translation initiation machinery through eIF4E-binding protein 1 inactivation. J Biol Chem. 2012; 287:5042-58.

21. Hsieh AC, Liu Y, Edlind MP, Ingolia NT, Janes MR, Sher A, Shi EY, Stumpf CR, Christensen C, Bonham MJ, Wang S, Ren $\mathrm{P}$, Martin $\mathrm{M}$, et al. The translational landscape of mTOR signalling steers cancer initiation and metastasis. Nature. 2012; 485:55-61.

22. Ryu SH, Jang MK, Kim WJ, Lee D, Chung YH. Metastatic tumor antigen in hepatocellular carcinoma: golden roads toward personalized medicine. Cancer Metastasis Rev. 2014; 33:965-80.

23. Pourdehnad M, Truitt ML, Siddiqi IN, Ducker GS, Shokat KM, Ruggero D. Myc and mTOR converge on a common node in protein synthesis control that confers synthetic lethality in Myc-driven cancers. Proc Natl Acad Sci USA. 2013; 110:11988-93.

24. Etiemble J, Degott C, Renard CA, Fourel G, Shamoon B, Vitvitski-Trépo L, Hsu TY, Tiollais P, Babinet C, Buendia MA. Liver-specific expression and high oncogenic efficiency of a c-myc transgene activated by woodchuck hepatitis virus insertion. Oncogene. 1994; 9:727-37.

25. de Chassey B, Navratil V, Tafforeau L, Hiet MS, AublinGex A, Agaugué S, Meiffren G, Pradezynski F, Faria BF, Chantier T, Le Breton M, Pellet J, Davoust N, et al. Hepatitis $\mathrm{C}$ virus infection protein network. Mol Syst Biol. 2008; 4:230.

26. Wendel HG, Silva RL, Malina A, Mills JR, Zhu H, Ueda T, Watanabe-Fukunaga R, Fukunaga R, TeruyaFeldstein J, Pelletier J, Lowe SW. Dissecting eIF4E action in tumorigenesis. Genes Dev. 2007; 21:3232-7.
27. Kamegaya Y, Hiasa Y, Zukerberg L, Fowler N, Blackard JT, Lin W, Choe WH, Schmidt EV, Chung RT. Hepatitis C virus acts as a tumor accelerator by blocking apoptosis in a mouse model of hepatocarcinogenesis. Hepatology. 2005; 41:660-7.

28. Machida K, Tsukamoto H, Mkrtchyan H, Duan L, Dynnyk A, Liu HM, Asahina K, Govindarajan S, Ray R, Ou JH, Seki E, Deshaies R, Miyake K, et al. Toll-like receptor 4 mediates synergism between alcohol and $\mathrm{HCV}$ in hepatic oncogenesis involving stem cell marker Nanog. Proc Natl Acad Sci USA. 2009; 106:1548-53.

29. Ruggero D, Montanaro L, Ma L, Xu W, Londei P, CordonCardo C, Pandolfi PP. The translation factor eIF-4E promotes tumor formation and cooperates with c-Myc in lymphomagenesis. Nat Med. 2004; 10:484-6.

30. Verga-Gérard A, Porcherot M, Meyniel-Schicklin L, André P, Lotteau V, Perrin-Cocon L. Hepatitis C virus/ human interactome identifies SMURF2 and the viral protease as critical elements for the control of TGF- $\beta$ signaling. FASEB J. 2013; 27:4027-40.

31. Zhong J, Gastaminza P, Cheng G, Kapadia S, Kato T, Burton DR, Wieland SF, Uprichard SL, Wakita T, Chisari FV. Robust hepatitis C virus infection in vitro. Proc Natl Acad Sci USA. 2005; 102:9294-9.

32. Podevin $P$, Carpentier A, Pène V, Aoudjehane L, Carrière M, Zaïdi S, Hernandez C, Calle V, Méritet JF, Scatton O, Dreux M, Cosset FL, Wakita T, et al. Production of infectious hepatitis $\mathrm{C}$ virus in primary cultures of human adult hepatocytes. Gastroenterology. 2010; 139:1355-64.

33. Wakita T, Pietschmann T, Kato T, Date T, Miyamoto M, Zhao Z, Murthy K, Habermann A, Kräusslich HG, Mizokami M, Bartenschlager R, Liang TJ. Production of infectious hepatitis $\mathrm{C}$ virus in tissue culture from a cloned viral genome. Nat Med. 2005; 11:791-6.

34. Rayapuram N, Bonhomme L, Bigeard J, Haddadou K, Przybylski C, Hirt H, Pflieger D. Identification of novel PAMP-triggered phosphorylation and dephosphorylation events in Arabidopsis thaliana by quantitative phosphoproteomic analysis. J Proteome Res. 2014; 13:2137-51.

35. Schroeder MJ, Shabanowitz J, Schwartz JC, Hunt DF, Coon JJ. A neutral loss activation method for improved phosphopeptide sequence analysis by quadrupole ion trap mass spectrometry. Anal Chem. 2004; 76:3590-8.

36. Olsen JV, Blagoev B, Gnad F, Macek B, Kumar C, Mortensen P, Mann M. Global, in vivo, and site-specific phosphorylation dynamics in signaling networks. Cell. 2006; 127:635-48. 